\title{
El patrocinio artístico de Bartolomé Martínez de Quintana e Isabel de Franqui en Palermo, Madrid y Moneo (Burgos) a comienzos del siglo XVII. Obras de Antonio de Herrera, escultor del rey, y Filippo Paladini, pintor florentino
}

\begin{abstract}
Artistic sponsorship of Bartolomé Martínez de Quintana and Isabel de Franqui between Palermo, Madrid and Moneo (Burgos) in the early 17th century. Works by Antonio de Herrera, royal sculptor, and Filippo Paladini, florentine painter
\end{abstract}

\author{
René Jesús Payo Hernanz y José Matesanz del Barrio \\ Universidad de Burgos
}

Fecha de recepción: 30 de enero de 2018

Fecha de aceptación: 17 de marzo de 2019
Anuario del Departamento de Historia y Teoría del Arte

vol. 31, 2019, pp. 115-137

ISSN: 1130-5517, eISSN: 2530-3562

https://doi.org/10.15366/anuario2019.31.006

\section{RESUMEN}

Bartolomé Martínez de Quintana, desarrolló importantes cargos en el gobierno del virreinato de Sicilia-donde casó con Isabel de Franchi (Franqui), que pertenecía a una noble familia genovesa instalada en Palermo-y en Madrid a finales del siglo XVI y en los primeros años del siglo XVII. Tanto en los territorios italianos como en la corte madrileña, este matrimonio adquirió una notable cantidad de pinturas y esculturas entre las que destacan las obras del pintor Filippo Paladini y del escultor real Antonio de Herrera Barnuevo. Algunas de estas obras acabaron formando parte del retablo mayor de Moneo (Burgos) que integra los lienzos de Paladini y las tallas de Herrera.

\section{PALABRAS CLAVE}

Antonio de Herrera Barnuevo. Filippo Paladini. Bartolomé Martínez de Quintana. Isabel de Franqui. Escultura y pintura de comienzos del siglo XVII. Madrid. Palermo. Moneo (Burgos).

\begin{abstract}
Bartolomé Martinez de Quintana held important positions in the Government of the Viceroyalty of Sicily. He married Isabel de Franchi (Franqui), who belonged to a noble Genoese family installed in Palermo and Madrid at the end of the 16th century and the beginning of the 17 th century. This couple acquired a significant amount of paintings and sculptures from both Italy and Madrid court, including some works of the painter Filippo Paladini and the Royal Sculptor Antonio de Herrera Barnuevo. Some of these works ended up being part of the main altarpiece of Moneo (Burgos) that integrates Paladini's canvases and Herrera's carvings.
\end{abstract}

\section{KEY WORDS}

Antonio de Herrera Barnuevo. Filippo Paladini. Bartolomé Martínez de Quintana. Isabel de Franqui. Sculpture and painting of the early 17 th century. Madrid. Palermo. Moneo (Burgos). 


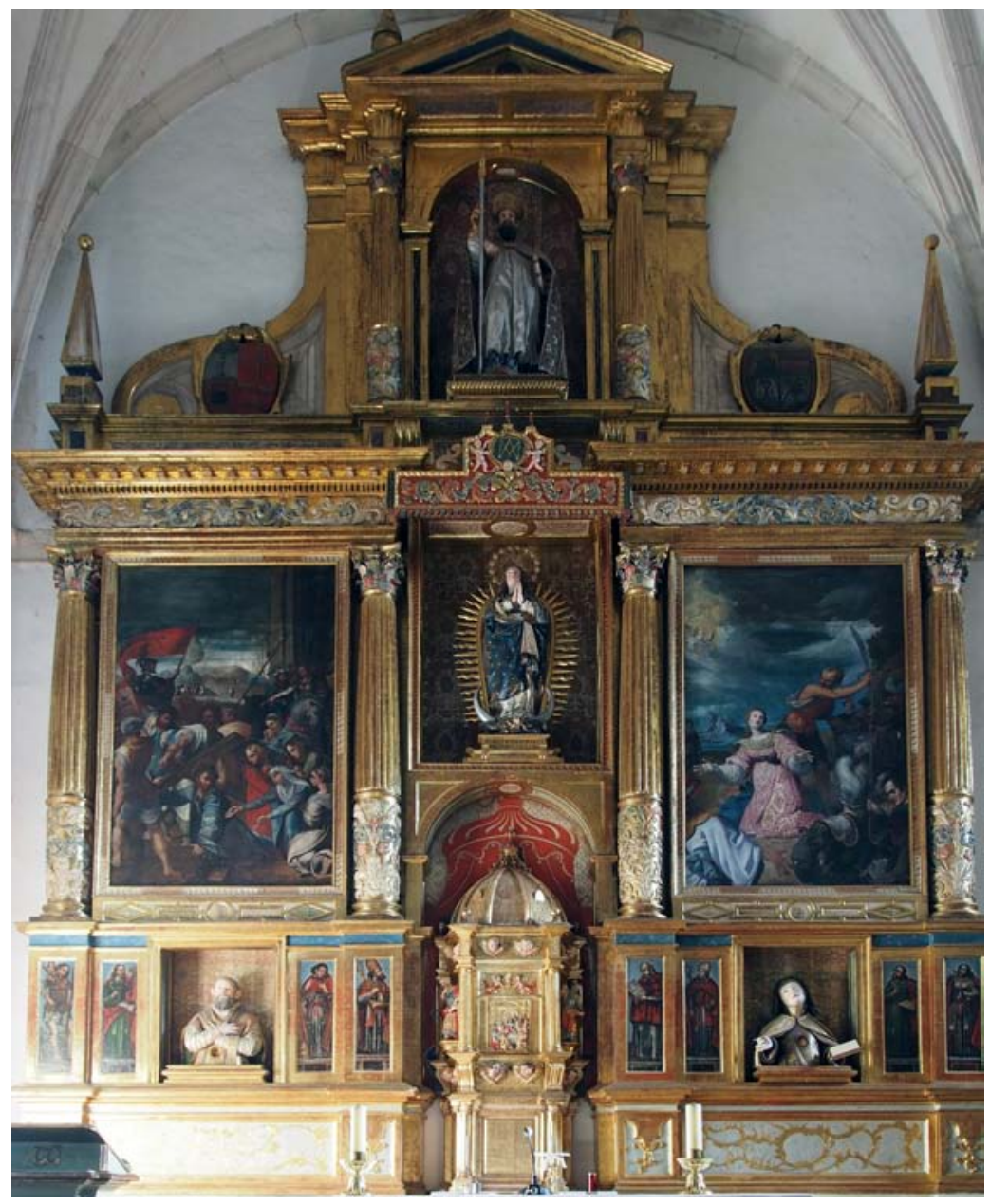

Fig. 1. Retablo mayor de Moneo (Burgos).

La riqueza del patrimonio burgalés se extiende a un numeroso conjunto de templos que albergan obras de arte de gran valor de diferentes épocas, ligadas no solo a la actuación de maestros del foco artístico local, sino también de otros entornos geográficos y talleres, merced a un patrocinio rico y diverso ${ }^{1}$. Este es el caso de la iglesia de San Saturnino de Moneo, población en las proximidades de Medina de Pomar que cuenta con un edificio de notables proporciones, de planta de salón, que reemplazaría en el siglo XVI y principios del XVII a una fábrica medieval a través de destacadas actuaciones realizadas en diferentes fases constructivas $^{2}$. Entre 1539 y 1549 se llevaría a cabo la obra de la cabecera y torre por Juan García de Ribas y Juan de Rivero, prosiguiéndose más adelante con la fábrica de las naves y la edificación, entre 1588 y 1590, del recinto privado del obispo de Pamplona Pedro de la Fuente que contó con la intervención escultórica de Juan de Ancheta y la probable factura arquitectónica de maestros canteros trasmeranos ${ }^{3}$.

1 Salvador Andrés Ordax, "El foco artístico burgalés", en La ciudad de Burgos. Actas del Congreso de Historia de Burgos, Junta de Castilla y León. Consejería de Educación y Cultura, Madrid, 1985, pp. 845-859.

2 Julio J. POLO SÁNCHEZ, "El modelo 'hallenkirchen' en la arquitectura del norte peninsular: el papel de los trasmeranos", en M.C. Lacarra Ducay (coord.), Arquitectura religiosa del siglo XVI en España y Ultramar, Zaragoza, Institución "Fernando el Católico", 2004, pp. 207-210.

3 Salvador ANDrÉs Ordax, "El retablo de Anchieta en Moneo", Boletín del Seminario de Estudios de Arte y Arqueología, 43 (1977), pp. 437-444. 
Este templo parroquial, que se enriquecerá con otras destacadas obras mobiliares fabricadas en el siglo $\mathrm{XVI}^{4}$, será renovado en el siglo XVII merced a la voluntad de Bartolomé Martínez de Quintana, natural de Moneo, y su esposa Isabel de Franqui, que materializará los deseos de su esposo remodelando el espacio de la capilla mayor y presbiterio, elegido como lugar de enterramiento para el matrimonio y miembros de su familia, y con la financiación de un nuevo retablo mayor en el que, junto a la presencia del sagrario, labrado en 1577, y la realización de otras obras en talleres burgaleses, se incorporarán varias pinturas y esculturas de su propiedad con un destacado valor (fig. 1).

Estas piezas, realizadas por artistas foráneos, tienen su origen en Sicilia y en la corte madrileña, entornos geográficos unidos a la biografía personal de ambos personajes ${ }^{5}$. Entre todas resaltan, por su importancia, las dos pinturas del pintor asentado en Palermo Filippo Paladini, una imagen de la Inmaculada Concepción, la talla de San Saturnino y los relicarios de Santa Teresa y San Felipe Neri, obras de Antonio de Herrera.

Durante la primera mitad del siglo XVII, Madrid ${ }^{6}$, reconocida por el rey Felipe II como capital de España en $1561^{7}$, alcanzó una señalada relevancia en el panorama artístico español ${ }^{8}$. La presencia de la corte será motor de numerosas empresas en las que participarán relevantes artífices que establecerán, bien temporal o definitivamente, su taller en ella ${ }^{9}$. Asimismo, Madrid verá llegar obras realizadas en otros puntos de España y en el extranjero ${ }^{10}$ para realzar entornos urbanos, edificios públicos, construcciones religiosas $^{11}$ y palacios ${ }^{12}$, costeadas en su mayoría por los grupos sociales más destacados de la ciudad que, como subraya Vicente Carducho, muestran un gran interés por su valor ${ }^{13}$.

Si dentro de las artes plásticas madrileñas de esta época la pintura es la principal de las manifestaciones figurativas ${ }^{14}$, no es menos cierto que la escultura alcanzó notables cotas a lo largo de este período, siendo Madrid un foco de atracción de escultores según muestran las actuaciones de significados imagineros como el portugués Manuel Pereira (1588-1683) ${ }^{15}$, Juan Sánchez Barba (1602-1673) $)^{16}$, Antonio de Riera (1578-1638) ${ }^{17}$, Antón de Morales (documentado entre 1589 y 1623) ${ }^{18}$, Antonio de Herrera

\footnotetext{
4 Antonio Gallardo Laureda, Iglesia de San Saturnino. Moneo. Guía para una visita, Parroquia de San Saturnino de Moneo, Burgos, 2001; Inocencio CAdĩ̃anos BARdeCí, Los aforados de Moneo, Asociación de Amigos de Medina de Pomar, Burgos, 2005.

5 Archivo General Diocesano de Burgos (en adelante AGDBu.), Moneo. Leg. 10.

${ }^{6} \mathrm{M}^{\mathrm{a}}$ del Carmen GonzÁlez MuÑoz, "Datos para un estudio de Madrid en la primera mitad del siglo XVII", Anales del Instituto de Estudios Madrileños, XVIII (1981), pp. 149-186.

7 Alfredo Alvar EzQuerra, "Los traslados de Corte y el Madrid de los Austrias", en El Madrid de Velázquez y Calderón Villa y Corte en el siglo XVII, Madrid, Caja Madrid, 2000, pp. 41-60.

8 Bernardo José García García, "La nueva Babilonia de España”, en El Madrid de Velázquez y Calderón Villa y Corte en el siglo XVII, Madrid, Caja Madrid, 2000, pp. 17-40.

9 Francisco Gutiérrez Carbajo, Relatos de Madrid (Siglos XVII-XIX), Madrid, Consejería de Educación y Cultura. Comunidad de Madrid, 1999, p. 8.

10 Delfín Rodríguez Ruiz (coord.), Bernini, Roma y la Monarquía Hispánica, Museo Nacional del Prado, Madrid, 2014.

11 Alicia CÁmara MuÑoz, "El orbe del Rey y el laberinto de Dios. Madrid, urbe manierista y barroca", Anales de Estudios Madrileños, 19 (1982), pp. 49-59.

12 José Miguel Morán Turina, "Los palacios de Madrid”, en El Madrid de Velázquez y Calderón Villa y Corte en el siglo XVII, Madrid, Caja Madrid, 2000, pp. 183-198.

13 Vicente CARDucho, Diálogo de la pintura, su defensa, origen, esencia, definición, modos y diferencias, Madrid, 1633 , p. 150.

14 Alfonso E. PÉrez SÁnchez, Pintura madrileña del primer tercio del siglo XVII, Madrid, CSIC, 1973, y Alfonso E. PÉREZ SÁncheZ, Pintura madrileña del segundo tercio del siglo XVII, Madrid, CSIC, 1983.

15 Rubén SÁnchez GuZMÁn, “El escultor Manuel Pereira (1588-1683)”, Cuadernos de Arte e Iconografia, T. 17, 33 (2008), pp. 6-278.

16 Juan Luis Blanco Mozo, “Juan Sánchez Barba (1602-1673) escultor”, Anuario del Departamento de Historia y Teoría del Arte, 15 (2003), pp. 79-98.

17 Jesús UrRea Fernández, "El escultor Antonio de Riera", Boletín del Seminario de Estudios de Arte y Arqueología, 40-41 (1975), pp. 668-672.

18 María Concepción GARCía GAINZA, "Significado y valoración de la escultura escurialense en el panorama artístico español”, en F.J. Campos y Fernández de Sevilla (coord.), La escultura en el Monasterio del Escorial: actas del Simposium, Instituto Escurialense de Investigaciones Históricas y Artísticas, San Lorenzo de El Escorial, 1994, pp. 269-286.
} 
Barnuevo (†1646), objeto de investigación en este trabajo, así como el retablista y arquitecto Alonso Carbonel (1583-1660) ${ }^{19}$.

La difusión de la actividad de este conjunto de escultores no solo tendría como destino la propia corte, sino que su arte irradiará a otros puntos del reino. Durante la primera mitad del siglo XVII el patrimonio religioso de la ciudad de Burgos y su diócesis se verá enriquecido con la presencia de un interesante conjunto de obras procedentes de la corte, a través de legados y nuevos proyectos artísticos de instituciones y particulares. Las principales instituciones religiosas burgalesas, como la Catedral de Burgos y la Cartuja de Miraflores, contarán con el auspicio del que fuera arzobispo y posteriormente cardenal, Antonio Zapata, que sufragó el coste del trascoro del Templo Mayor burgalés en el que se dispusieron dos esculturas de San Pedro y San Pablo, labradas en 1623 por Antonio de Riera ${ }^{20}$, y entregó al monasterio de la Cartuja, fundación en la que profesaba un sobrino, una escultura de San Bruno debida a la gubia de Manuel Pereira en los años 1634 y 1635 y policromada por Jusepe Leonardo ${ }^{21}$. Perteneciente, muy probablemente, al legado del convento de San Francisco de Burgos, se exhibe en la capilla del Palacio Real de Valladolid la imagen de un Ecce Homo atribuido a Juan Sánchez Barba $(1602-1673)^{22}$.

Junto a la antigua Caput Castellae otras localidades y centros religiosos burgaleses también albergarán obras de pintura y de escultura realizadas en el entorno de la corte en esta época. Así lo certifican las fundaciones lermeñas del valido del rey Felipe III, Francisco Gómez de Sandoval y Rojas y sus parientes ${ }^{23}$, y el monasterio de Santa Clara de Medina de Pomar $^{24}$, vinculado al linaje de la familia Fernández de Velasco, que había establecido ya su residencia en Madrid, poblaciones que cuentan con notables obras de Gregorio Fernández junto a otros trabajos de ilustres imagineros y pintores cortesanos. En este contexto han de encuadrarse las piezas que conforman el retablo de Moneo (Burgos).

\section{Bartolomé Martínez de Quintana e Isabel de Franqui y sus colecciones artísticas entre Palermo y Madrid}

El 3 de febrero de 1628 falleció en Madrid Bartolomé Martínez de Quintana ${ }^{25}$, nacido en la segunda mitad del siglo XVI en la localidad de Moneo, situada en las "Merindades de Castilla Vieja" en las proximidades de Medina de Pomar, adscrita a la Junta de Avellaneda en las Encartaciones ${ }^{26}$. Tal como subraya en su testa-

\footnotetext{
19 Juan Luis Blanco Mozo, Alonso Carbonel (1583-1660). Arquitecto del Rey y del Conde-Duque de Olivares, Madrid, Fundación Universitaria Española, 2007.

20 Juan José Martín González, "Dos esculturas de Antonio de Riera en la Catedral de Burgos”, Boletín del Seminario de Estudios de Arte y Arqueología, 53 (1987), pp. 360-363.

21 SÁnchez GuZmán, 2008, pp. 87-89.

${ }^{22}$ La citada escultura se encontraba entre los bienes de un polvorín de Orbaneja, y en origen del convento de San Francisco de Burgos.

23 Luis Cervera Vera, Bienes muebles en el palacio ducal de Lerma, Valencia, Editorial Castalia, 1967; Sara Schroth, The Private Picture Collection of the Duke of Lerma, tesis doctoral, Nueva York, 1990; René Jesús PaYo HeRnanZ, Lerma, Burgos, Centro de Iniciativas Turísticas de Lerma, 2004.

24 VV.AA., El monasterio de Santa Clara de Medina de Pomar. Fundación y Patronazgo de la Casa de los Velasco, Burgos, Asociación Amigos de Santa Clara, 2004.

25 Archivo Histórico Provincial de Madrid (en adelante AHPM), Leg. 6581, fol. 600 vo . Antonio Cadenas. Contiene el testamento de Isabel de Franqui dado el 24 de marzo de 1641 ante el escribano Antonio Gutiérrez. El día 2 de febrero de 1628 , ante el escribano Felipe de Liébana, y en estado de extrema gravedad, tras padecer largos años la enfermedad de gota, Bartolomé Martínez de Quintana autorizó que el padre Lorenzo de Aponte y a su esposa Isabel de Franqui pudieran redactar testamento en su nombre, de acuerdo a un memorial que dejó escrito (AHPM. Leg. 2681, fols. 468 r -469 vo , Francisco Testa).

${ }^{26}$ Luis Miguel Díez de Salazar Fernández, "Pueblos castellano-viejos aforados. El fuero de Vizcaya y Encartaciones (Siglos XIV-XVI)", en Congreso de estudios históricos: Vizcaya en la Edad Media, San Sebastián, Eusko Ikaskuntza, 1986, pp. 309-318.
} 
mento ${ }^{27}$, Bartolomé era hijo de Lucas de Quintana y Casilda Álvarez, afincados en esta villa burgalesa en la que contaban con diversas propiedades ${ }^{28}$. Los libros parroquiales de la iglesia de San Saturnino, así como distinta documentación notarial burgalesa y madrileña, dan buena medida del relieve de esta progenie, que contó entre sus miembros con varios integrantes del clero entre los que se encuentran sus primos Gaspar y Marcos Martínez de Quintana ${ }^{29}$, que guardarán a lo largo de su vida estrecha relación con Bartolomé, así como otro familiar suyo de nombre Antonio de Quintana que, como él, residirá gran parte de su vida en Palermo.

La presencia de Bartolomé Martínez de Quintana en Italia ya en la última década del siglo XVI, tendrá una importante repercusión en su vida tanto desde el punto de vista profesional y social como en el personal, tal como subrayan diferentes informaciones contenidas en papeles notariales, relaciones y obras literarias. Sabemos que Martínez de Quintana estuvo al servicio de Enrique de Guzmán, conde de Olivares, que a lo largo de su vida desempeñó importantes oficios y ostentó los cargos de tesorero mayor de Castilla, alcaide del Alcázar de Sevilla, embajador español en Francia y Roma, virrey de Sicilia y Nápoles y consejero de estado. La relación de Martínez de Quintana con el linaje de los Guzmán quedará avalada por la publicación de sendos poemas laudatorios dedicados a los hijos de este distinguido noble español: Jerónimo $^{30}$, que fallecería en su infancia, y Gaspar ${ }^{31}$, futuro conde-duque de Olivares. Estas obras literarias nos permiten conocer su faceta como escritor festivo (fig. 2).

Durante su estancia en Sicilia el papel político y administrativo desempeñando por Bartolomé Martínez de Quintana fue muy relevante, ocupando a fines de la decimosexta centuria el cargo de Secretario de Estado y Guerra en el virreinato ${ }^{32}$, oficio que desempeñaba el burgalés a la llegada del nuevo virrey, Bernardino de Cárdenas y Portugal ${ }^{33}$, III duque de Maqueda, adelantado mayor del Reino de Granada, virrey de Cataluña y de Sicilia, a quien serviría en esta tierra hasta su muerte el 17 de diciembre de 1601. Posteriormente asistirá a su hijo Jorge de Cárdenas Manrique formando parte de su séquito en la jornada de Argel, y a su viuda Elena Manrique de Lara ${ }^{34}$, duquesa de Nájera, a quien acompañará más tarde a España, atendiendo sus negocios hasta el año de 1610, como relata en el pliego de últimas voluntades. El

27 Existen dos ejemplares de testamento y últimas voluntades, consignados ante los escribanos madrileños Francisco Testa, y Luis Ordóñez, que lo incorporará en un documento de partición de bienes. El documento de últimas voluntades será avalado por fray Toribio López de Celada, Plácido Carrillo, cuñado suyo, Gabriel Álvarez de Rabanal y Francisco Hidalgo. Actuarán como testamentarios su viuda Isabel de Franqui de Quintana y el Padre Lorenzo de Aponte, religioso de los clérigos menores. Serán nombrados también como albaceas testamentarios Andrés de Rozas, sobrino del finado, y Gaspar de Quintana.

28 AHPM. Leg. 2681, fol. 479 v , Francisco Testa. Testamento del secretario Bartolomé Martínez de Quintana. Contiene un memorial del secretario certificado por Francisco Díaz. El libro I del archivo parroquial de Moneo del AGDBu. señala que en 1600 falleció Lucas Martínez, personaje que, tal vez, pueda ser el padre de Bartolomé Martínez de Quintana.

29 Pedro Martínez de Quintana es párroco de la iglesia de Moneo en la segunda mitad del siglo XVI. Sus primos, el licenciado Gaspar Martínez de Quintana, residente en Burgos, fue arcipreste de Rojas y capellán del Hospital de la Concepción de Burgos y Marcos Martínez de Quintana, beneficiado en Medina de Pomar. Este personaje debía de ser hijo de otro Marcos Martínez de Quintana que fue escribano del rey. En su testamento Bartolomé Martínez de Quintana legará sus propiedades de Moneo a su primo Gaspar.

30 Bartolomé Martínez de Quintana, Canción Primera de Bartolomé Martínez de Quintana al Ilustrissimo Señor D. Hieronimo de Guzman, succesor de la Casa de Olivares. Con anotaciones de don Luis de Heredia, Palermo, Filipo Paruta, 1594. En el texto introductorio a esta canción, Martínez de Quintana, deja constancia de la devoción "a su nombre, i al de su Excelentissima casa".

31 Bartolomé Martínez de Quintana, Canción a la niñez del Excmo. Sr. D. Gaspar de Guzmán, Conde Duque de Olivares, Perpiñán, Esteban Bartau, 1637. Esta obra fue editada, ya tras su muerte, por su cuñado Plácido Carrillo y Aragón, y en ella intervendrán también Miguel Soberá, Alonso de Villamayor y Bernardo de Bravo y Sotronca.

32 Sobre el papel de los Secretarios de Estado y Guerra ver el artículo de Roberto Quirós Rosado, "Las secretarías de Estado y Guerra en la monarquía de Carlos VI: ¿vía hacia una planta ejecutiva?”, en Campo y campesinos en la España Moderna. Culturas políticas en el mundo hispano, Madrid, Fundación Española de Historia Moderna, 2012, pp. 1581-1592.

33 Carlos GonzÁlez Reyes, “La génesis de un 'alter ego' de Felipe II. Don Bernardino de Cárdenas y Portugal, un noble al servicio de la monarquía”, en Felipe II y Almazarrón: la construcción local de un imperio global, 2, Murcia, Universidad de Murcia, 2014, pp. 227-240.

34 Doña Luisa (1558-1627) fue hija de Juan Manrique de Lara y María Girón de la Cueva, y hermana de Juan Manrique, que murió sin sucesión, heredando con tal motivo el título de duquesa de Nájera. 


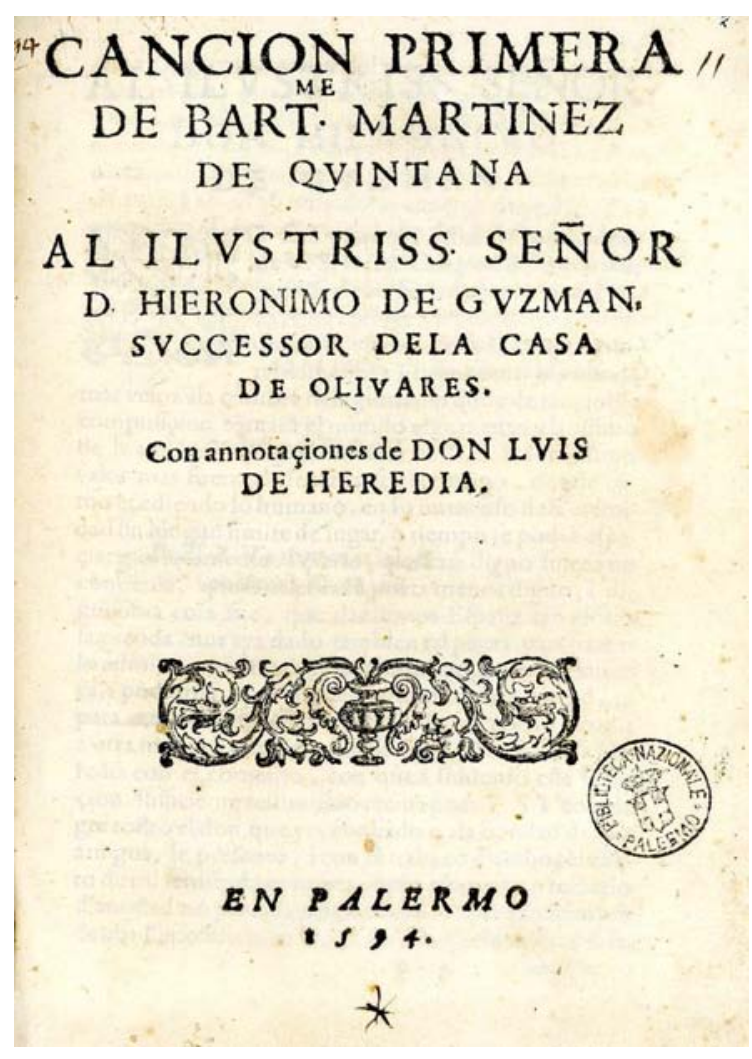

Fig. 2. Canción Primera... de Bartolomé Martínez Quintana. Palermo, 1594.

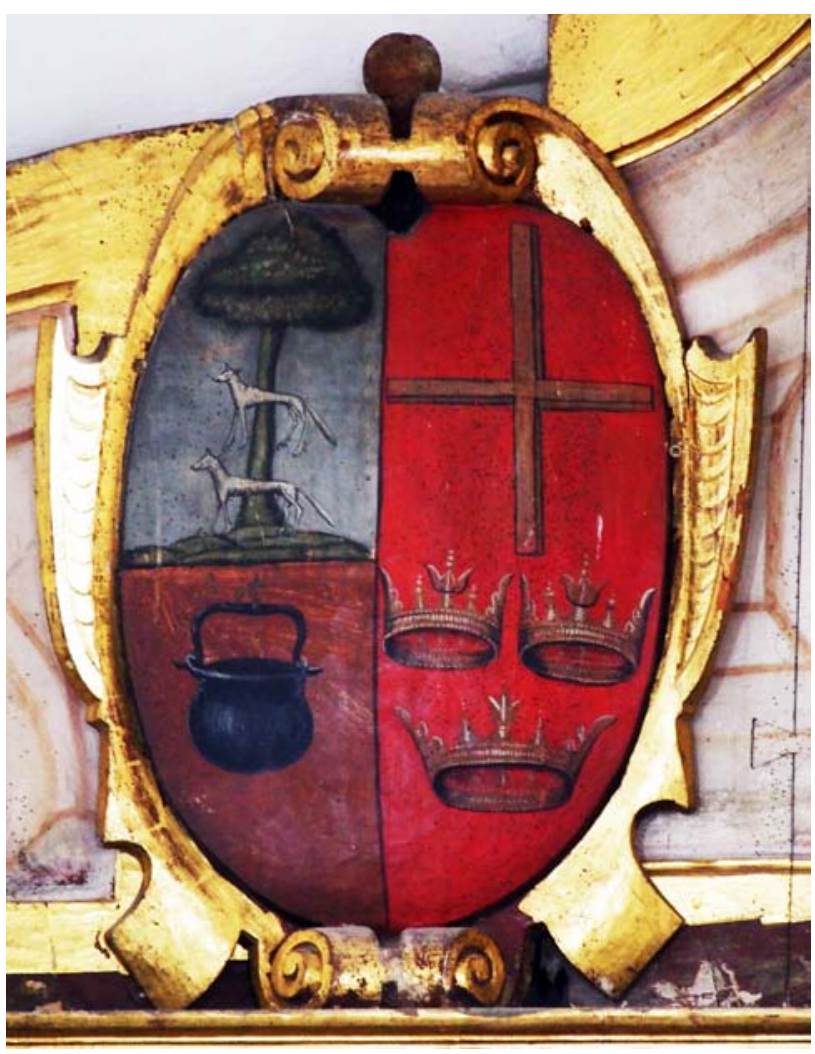

Fig. 3. Escudo de la familia Franchi. Retablo mayor de Moneo (Burgos).

reconocimiento de la labor administrativa llevada a cabo por Martínez de Quintana en Palermo, donde ocuparía asimismo el cargo de sobrestante mayor del tercio de infantería, tendría un refrendo por parte del rey Felipe III con la concesión en 1602 de una renta anual de 150 escudos en atención a sus servicios ${ }^{35}$.

En paralelo a este relieve público alcanzado por Bartolomé Martínez de Quintana, hemos de subrayar su plena integración en la comunidad palermitana que se formalizará en su matrimonio el año de 1596 con Isabel de Franchi (apellido castellanizado en España como Franqui) ${ }^{36}$, hija de Giovanni Battista de Franchi y Doralice Musso y Branchi, personajes principales de la capital siciliana. Así lo confirma el árbol genealógico de los dos progenitores. Su padre ${ }^{37}$ era vástago del que fuera dux de Génova Gerolamo de Franchi Toso (1522-1586) ${ }^{38}$ y su esposa Isabella Sauli ${ }^{39}$, heredera de una de las más destacadas familias de la capital ligur ${ }^{40}$. Por línea de su madre, sabemos que Doralice Musso y Branchi, era hija de Francesco Musso o

35 AHPM. Leg. 5006, fols. 325 r-325 vº Luis Ordóñez. Madrid, 2 de febrero de 1628.

36 En España el apellido se castellanizó como Franqui.

37 Su padre falleció cuando ella tenía la edad de 6 meses. Será su tutor Juan Antonio de Oliva.

38 Será dux de Génova desde 1581 a 1583, cargo que desempeñarán también su hijo Federico de Franchi desde 1623 a 1625 y sus nietos, primos de Isabel de Franqui, Giacomo de Franchi, dux en los años 1648-1650 y Girolamo de Franchi entre 1652 y 1654. En la ciudad de Génova se conserva el palacio familiar reconstruido por Bernardo y Giuseppe Franchi en 1562, así como la memoria de fundaciones particulares en las iglesias de San Francesco di Castelleto, desaparecida, y San Francisco de Albaro.

39 Mario Bologna, L'archivio della familia Sauli di Genova, Publicazione degli Archivi di Stato Strumenti CXLIX, Génova, Ministerio per i beni e le attività culturali. Direzione Generale per gli Archivi, 2001.

40 Natale Battilana, Genealogie delle famiglie nobili di Genova, Génova, Pagano, 1825-1833 y Angelo ScorzA, Libro d'Oro della Nobilità di Genova, Edizioni Orsini de Marzo (reedición de un original de 1920). 
Moso y Giovanna Branchi y Santa Coloma, cuyos apellidos nos hablan de otras importantes estirpes que tenían raíz en Liguria y Piamonte ${ }^{41}$, así como en la Toscana ${ }^{42}$ y en Cataluña ${ }^{43}$ (fig. 3).

La elevada posición social alcanzada por el matrimonio tuvo su correlato en el importante conjunto de bienes inmuebles y muebles poseídos ${ }^{44}$ que aparecen citados en la documentación, resaltando entre todos ellos el domicilio radicado en la céntrica calle de la Bandiera de Palermo ${ }^{45}$ y una heredad en la localidad de Capaci, conocida con el nombre de Falconer. Asimismo, Isabel de Franqui será beneficiaria, junto a su hermano Plácido Carrillo Muso y Branchi, también conocido como Plácido Carrillo y Aragón, de varios censos y rentas por diversas propiedades en Palermo y el suministro de agua a distintos particulares.

Al regreso de Bartolomé Martínez de Quintana a España se establecerá con su esposa en Madrid en unas casas situadas en la calle de la Ballesta ${ }^{46}$, vía que, tal como muestra el plano de Teixeira de 1656, comunicaba la calle de la Corredera de San Pablo con la de Desengaño. Dicha mansión había sido comprada a Inés Vázquez de Mendoza, viuda de Sebastián Ortiz de Ibarra ${ }^{47}$, y era lindante con las casas de Elena de Mendoza, Juan Montero de Vallejo ${ }^{48}$ y Juan de Espina en la parroquia de San Martín.

Las fuentes documentales consultadas subrayan que Bartolomé Martínez de Quintana continuó sirviendo hasta el año 1610 a la duquesa de Nájera, que le asignaría un salario anual de 1.000 ducados $^{49}$. Posteriormente lo haría con su hijo, el IV duque de Maqueda, como secretario y gobernador de sus estados. En expediente iniciado en 4 de julio de 1616 le nombró juez de residencia del estado de Maqueda en razón de "las partes y cualidades que se requieren" oficio del que, debido a una larga enfermedad de gota ${ }^{50}$, no había podido tomar posesión en enero de 1620 , concediéndosele posteriormente una pró$\operatorname{rroga}^{51}$. El notorio valor alcanzado por Martínez de Quintana en su oficio de secretario, que había ejercido 30 años al servicio de la casa noble de Maqueda, sería reconocido por sus contemporáneos, siendo uno de los personajes que darán su aprobación al libro de Gabriel Pérez del Barrio Angulo Dirección de Secretarios de Señores..., publicado en su primera edición en Madrid por Alonso Martín de Balboa $^{52}$.

El agravamiento progresivo de su estado de salud tendría por desenlace su óbito ya señalado el día 3 de febrero de 1628, siendo depositado inicialmente su cuerpo en la capilla mayor del convento de San Basilio, vecino a su mansión. No será, sin embargo, este cenobio el lugar donde reposarán definitivamente sus restos ni en el del Carmen Calzado, como indica en cláusula testamentaria. En el documento de últimas voluntades, así como en el posterior testamento, Bartolomé Martínez de Quintana pide "tras-

41 El apellido Musso se extiende por Liguria y Piamonte.

42 El apellido Branchi aparece ligado a una familia originaria de Catelflorentino y presenta en su armorial uno o dos leones.

43 Así lo indica el apellido Santa Coloma de su madre Giovanna.

44 AHPM. Francisco Testa. Leg. 2681, fol. 462 r. Fueron tasados por un valor de 368 onzas.

45 Esta calle delimita con el barrio del mercado del Capo y en ella se encuentran notables edificios como el palacio Alliata di Pietratagliata (siglo XV), anteriormente perteneciente a la familia Termine, y el palacio Oneto di Sperlinga, residencia del siglo XVIII.

46 Fue adquirida por Bartolomé Martínez de Quintana con rentas de su propia fortuna.

47 Josef Antonio Álvarez Baena, Hijos de Madrid, ilustres en Santidad, dignidades, armas, ciencias y artes, I, Madrid, Oficina de D. Benito Cano, 1789, p. 48.

48 AHPM. Leg. 6581, fol. $611 \mathrm{v}^{\mathrm{o}}$. Antonio Cadenas. Contiene el testamento de Isabel de Franqui dado el 24 de marzo de 1641 ante el escribano Antonio Gutiérrez.

49 AHPM. Leg. 2681, fol.464 r. Francisco Testa. Testamento del secretario Bartolomé Martínez de Quintana. 12 de marzo de 1628.

50 En las instrucciones testamentarias subraya que estuvo enfermo a lo largo de 11 años.

51 Archivo Histórico de la Nobleza. BAENA. C. 114, D. 35-36. Nombramiento como juez de residencia a favor de Bartolomé Martínez de Quintana, efectuado por Jorge de Cárdenas Manrique, IV duque de Maqueda. Como gobernador de los estados de Maqueda tenía potestad sobre las villas de Maqueda, Torrijos, San Silvestre y Alcabón.

52 Gabriel Pérez del Barrio Angulo, Dirección de Secretarios de Señores, y las materias, cuydados, y obligaciones que les tocan, con las virtudes de que se han de preciar, estilo, y orden del despacho y expediente, manejo de papeles de ministros, formularios de cartas, provisiones de oficios, y un compendio en razón de acrecentar estado, y hazienda, oficio de Contador, y otras curiosidades que se declaran en la primera hoja, Madrid, Alonso Martín de Balboa, 1613. 
ladar sus huessos quando a sus testamentarios paresciesse a la Iglesia de San Saturnino de la Villa de Moneo" 53 , templo parroquial al que favorecerá con la creación de una fundación para casamiento de doncellas huérfanas con 4.000 ducados de principal. Detallando la primera de estas dos disposiciones, el secretario subrayó que deseaba ser enterrado a los pies del altar mayor en el costado del evangelio, para lo que solicitaba que se comprara una tumba a la que también habrían de ser llevados los restos de su abuelo Marcos de Quintana, que se encontraban sepultados en dicho templo, debiéndose disponer sobre la fosa una lápida que indicase el promotor de la obra y el nombre de las personas allí enterradas. Este deseo irá completado con la voluntad de alhajar el presbiterio, disponiendo un nuevo retablo en las condiciones que determinasen su esposa y su primo, Gaspar Martínez de Quintana. Tras la muerte de Gaspar Martínez de Quintana, Isabel de Franqui se hará cargo del proyecto, culminando el deseo manifestado por su esposo con la intervención de Lucas Ibáñez de Ibargüen, regidor y vecino de la villa de Medina de Pomar, que representó a la viuda del secretario en la firma de algunos documentos.

En el testamento cerrado de Isabel de Franqui, incluido en la notaría de Antonio de Cadenas ${ }^{54}$ y firmado en 24 de marzo de 1641 ante el escribano Antonio Gutiérrez, se aportan datos de gran valor que nos hablan de la compra para entierro del matrimonio en Moneo del "altar mayor de su iglesia parroquial desde la primera grada a la última" 55 , lugar donde en 1638 se habían depositado ya los restos de Bartolomé Martínez de Quintana y su sobrino Juan Carrillo y Aragón.

Por lo que respecta a la realización del retablo, sabemos que en 27 de septiembre de 1637 ante el escribano de Medina de Pomar Alejo de Ceballos se firmó un concierto por valor de 1.500 ducados, destinados a gastar en su factura y para la dotación de otros ornamentos a la iglesia ${ }^{56}$, subrayando que se habían enviado en cuatro cajas este conjunto de objetos ${ }^{57}$, "hornamentos e ymaxenes" propios de Isabel de Franqui, valorados en 7.084 reales según una tasación realizada por artífices peritos los últimos días de marzo de $1635^{58}$. La labor de peritaje efectuada estuvo a cargo del pintor italiano Angelo Nardi ${ }^{59}$ en lo que respecta a esculturas y pinturas, encargándose de la apreciación de las piezas textiles el sastre Alonso de Oñate. La presencia de Nardi como tasador de las obras de imaginería y pintura propiedad de Isabel de Franqui enviadas por la viuda de Bartolomé Martínez de Quintana a la iglesia parroquial de San Saturnino de Moneo, se relaciona con el trabajo de peritaje realizado en 1628 a la muerte del secretario por el mismo artista ${ }^{60}$, junto con el escultor Antonio de Herrera Barnuevo, el platero Luis de Melgar

53 AHPM. Leg. 2681, fols. 460 vo-461 r. Francisco Testa. Testamento del secretario Bartolomé Martínez de Quintana. 12 de marzo de 1628 .

54 AHPM. Leg. 6581, fols. 595 r - 618 vº. Antonio Cadenas. Testamento de Isabel de Franqui. Fueron testigos Pablo Aguila Bullón, Francisco Agulla Bullón, Pedro Antonio Celi, Manuel de Herrera, Antonio de Escobar, Antonio de Herrera Barnuevo y Jerónimo de Silva.

55 AHPM. Leg. 6581, fol. 599 vº. Antonio Cadenas. Testamento de Isabel de Franqui dado ante el escribano Antonio Gutiérrez el 24 de marzo de 1641 .

56 AHPM. Leg. 6581, fol. 602 r. Antonio Cadenas.

57 El coste de las cajas en que se metieron estas piezas fue de 98 reales, siendo el coste del porte hasta la villa de Moneo de 157 reales. AHPM. Leg. 6581, fols. 602 r - 602 vo. Antonio Cadenas.

58 AGDBu. Moneo. Leg. 10. Tasación de ornamentos. Madrid, 29 de marzo de 1635.

59 Angelo Nardi nació en 1584 en la localidad italiana de Vaglia de Mugello en el seno de una familia noble desposeída de su fortuna por los Medicis. Su primera formación se llevaría a cabo en la Toscana y posteriormente en Venecia, ciudad en la que permaneció hasta su venida a España en 1607, instalándose en Madrid donde ejerció una fecunda carrera hasta su muerte en 1664 y trabajó para otros territorios de España. En 1627 fue nombrado pintor del rey y en 1631 pintor de cámara, relacionándose con otros artífices contemporáneos como Vicente Carducho y Diego Velázquez. Asimismo, trabajará junto con maestros de otras especialidades en diferentes proyectos, coincidiendo con Antonio de Herrera Barnuevo en la obra para las Bernardas de Alcalá de Henares, promovida por el arzobispo Bernardo Sandoval y Rojas, así como posteriormente en trabajos para las iglesias de Vallecas y de Santa Cruz en Madrid.

60 La labor como tasador efectuada por Nardi en la ciudad de Madrid ya era apreciada en 1628, habiendo llevado a cabo en 1618 la tasación de pinturas del jurado de Baeza Gaspar de Ledesma Mariño. Ver Marcus B. Burke y Peter Cherry, Collections of paintings in Madrid 1601-1755, 2 vols., The J. Paul Getty Trust, 1997, p. 1.623. 
y el sastre Juan de Arjona. Su viuda, que queda por heredera de estos bienes, había aceptado los mismos "con beneficio de ynbentario" 61 .

El documento de inventario de bienes, firmado junto al testamento cerrado ante Cristóbal de Herrera e incorporado en los papeles del escribano Luis Ordóñez, es especialmente interesante por lo que respecta al conocimiento de los bienes muebles artísticos del matrimonio y, sobre todo, en lo referente a la relación de imágenes escultóricas que aparecen en la escritura, que serán base relevante para esclarecer datos de cronología, iconografía, elementos formales y materiales de algunas piezas que se trasladarán a Moneo. El día 26 de mayo de 1628 se llevará a cabo por Antonio de Herrera, "escultor de su magestad y aparejador de sus obras reales", el trabajo de tasación de los escritorios, sillas, bufetes y otros objetos de madera, entre los que destacan las imágenes escultóricas que poseía el matrimonio, resaltando por su relieve las que se hallaban en el oratorio privado ${ }^{62}$, obras que ya había registrado Isabel de Franqui en una relación llevada a cabo en 13 de febrero de dicho año ${ }^{63}$.

La presencia de Antonio de Herrera en la realización de este trabajo obedece a varios factores, como lo es, en primer lugar, el que fuera uno de los más relevantes escultores de la época e indican sus apelativos ya señalados de escultor de su majestad, obtenido en 1623, y de aparejador en 1627 que, además de su labor artística, también se ocupaba de intervenir en labores de peritaje. Asimismo, también certifica una relación estrecha de vecindad con Bartolomé Martínez de Quintana y su esposa ${ }^{64}$, refrendada en varia documentación. El día 21 de enero de 1616, Antonio de Herrera Barnuevo firmará un documento de reconocimiento de deuda con el secretario Bartolomé Martínez de Quintana por un préstamo, hecho en el que también figura como testigo el escultor Juan Sánchez Barba, cuñado de Herrera ${ }^{65}$.

Los datos extraídos del inventario de imágenes reflejan el elevado número de esculturas presentes en el domicilio del secretario burgalés que alcanza un número superior a las cuarenta y cinco, con un contenido casi exclusivamente religioso en el que destacan asuntos como la vida de Cristo y el misterio de la Inmaculada Concepción $^{66}$ (lo que evidencia una acumulación devocional), elaboradas tanto en madera posteriormente policromada, como en pasta, en marfil, o realizadas a través del vaciado metálico en bronce, estaño y plomo. El documento describe tres imágenes de Cristo crucificado, un Cristo atado a la columna, cinco tallas de la Virgen en diferentes misterios y advocaciones entre las que destaca la Inmaculada Concepción, varias esculturas de Niño Jesús de vestir, iconografía muy difundida en España en el siglo XVII ${ }^{67}$, representaciones de

61 AHPM. Leg. 5006, fols. 386 r - 414 r. Luis Ordóñez. Tasación de los bienes que quedaron a la muerte de Bartolomé Martínez de Quintana en su vivienda de la calle de la Ballesta.

62 Recientes investigaciones subrayan la importancia de los conjuntos escultóricos y pictóricos que albergaban oratorios privados, presentes en las moradas de las principales casas nobles y miembros de la oligarquía hispana. Sobre los oratorios privados y su importancia artística en los siglos XVII y XVIII debemos reseñar investigaciones recientes: Natalia GoNZÁLEZ HERAS, "La religiosidad doméstica de las élites al servicio de la Monarquía en el siglo XVIII”, Cuadernos de Historia Moderna, XIV (2015), pp. 85-106.

63 AHPM. Leg. 5006, fols. 373 v - 375 r. Luis Ordóñez. Inventario de los bienes que quedaron a la muerte de Bartolomé Martínez de Quintana en su vivienda de la calle de la Ballesta realizado por Isabel de Franqui.

${ }^{64}$ La documentación referente a Antonio de Herrera Barnuevo señala que el escultor tendría su domicilio desde 1615 en la calle de la Ballesta, en la que también vivía matrimonio Quintana-de Franqui. La vinculación personal de Antonio de Herrera Barnuevo con Isabel de Franqui continuará tras la muerte de su marido, siendo uno de los testigos que certifiquen en 1655 su fallecimiento, como también lo hará su hijo Manuel.

65 AHPM. Leg. 4855, fol. 447 r. 21 de enero de 1616. Documento citado por José Manuel Cruz VALDovinOs, "Noticias sobre el escultor madrileño Juan Sánchez Barba /1602-1670) y su familia”, Anales de Historia del Arte, 1 (1989), p. 204.

66 A lo largo del siglo XVII se produjo en España una gran difusión del culto inmaculista como subrayan las actas del congreso coordinado por Francisco CAMPOS Y FERNÁNDEZ DE SEVILla, La Inmaculada Concepción en España. Religiosidad, historia y arte, El Escorial, Real Centro Universitario Escorial-María Cristina. Ediciones Escurialenses, 2005. Pablo GONZÁLEZ TORNEL estudia con detalle la difusión visual de esta causa teológica en su trabajo "Arte y dogma. La fabricación visual de la causa de la Inmaculada Concepción en la España del siglo XVII”, Magallánica. Revista de Historia Moderna, vol. 3, 5 (2016), pp. 68-98.

67 María Teresa Vega Giménez, Imágenes exentas del Niño Jesús. Historia, iconografía y evolución (Catálogo de la provincia de Valladolid), Valladolid, Caja de Ahorros Provincial de Valladolid, 1984; Ángel ArocA LARA, "Iconografía de la imagen 
los santos Justo y Pastor, San Felipe Neri y Santa Teresa, además de distintas figuras de ángeles, y otras obras de temáticas diversas ${ }^{68}$.

El testamento de Bartolomé Martínez de Quintana puntualiza la devoción del secretario hacia distintas advocaciones, algunas presentes entre sus esculturas, que solemnizará en la fundación de capellanías en la parroquia de Moneo con vísperas y misa cantada presidida por diácono y subdiácono el día de "la fiesta de la purisima Conçebcion de la birjen maria"69, así como la celebración de diferentes actos litúrgicos en las festividades de San Felipe Neri, el 25 de mayo, de San Joaquín y Santa Ana, San José, San Isidro y Santa Catalina de Alejandría.

A través del inventario de bienes podemos conocer las características que presenta cada una de las esculturas en él referidas, tanto por lo que respecta a su identificación iconográfica, como a otros datos de índole formal y material, amén de su valoración económica. El lugar más destacado de todo el conjunto lo tenía "una ymaxen de n(uestr)a sen(or)a de la Limpia Concepcion... de todo relieve dorada y estofada y encarnada con su peana y rayos de madera de cinco quartas de alto taso el dicho ant(oni)o de herr(er)a la hechura en mil seiscientos y cinquenta y cinco Reales". Esta descripción nos recuerda a otras piezas de esa época, como la que encargó el 28 de septiembre de 1622, con destino al convento de San Francisco de Madrid, Cristóbal de Medina "imagen de nuestra señora de la limpia conçepçion con su peana y dragon y rayos ... unos recuadros y en ellos pintados los atributos al modo de la caja de $\mathrm{N}^{\mathrm{a}} \mathrm{S}^{\mathrm{a}}$ de la conçepçion de las descalças"70, obra también de Herrera Barnuevo que, como veremos, formaba parte de una serie que tuvo una gran repercusión en el ámbito artístico madrileño. En segundo lugar, debemos reseñar una talla de Cristo atado a la columna "de vara y media de alto" también policromada y encarnada como la anterior, tasada en 900 reales. A continuación, el inventario dirige su mirada a una imagen de la Virgen de la Soledad, "manos y caveça armado de madera vestida", apreciada en 50 ducados, 440 reales.

Junto a estas piezas, Antonio de Herrera Barnuevo destacaría una escultura fabricada en estaño posteriormente policromado de la Virgen entronizada con el Niño, apreciada en 330 reales; un Cristo crucificado de metal policromado tasado en 300 reales; una escultura de un Niño Jesús de madera policromada, que alcanzará la cuantía de 300 reales; dos figuras de medio cuerpo correspondientes a San Felipe Neri, "dorado y estofado", con hechura valorada en 300 reales, así como una talla de semejantes características, con la efigie de Santa Teresa, aún no policromada (se describe en madera blanca), tasada en 150 reales y un Cristo de bronce y cruz de madera, con valor de 17 ducados.

En el inventario aparecían unas cincuenta pinturas de temática esencialmente religiosa, aunque también existían algunas de carácter profano como una imagen de un sátiro marino, vanitas, retratos, paisajes y pinturas de batallas. Podemos sospechar que algunas de estas piezas, muchas de ellas valoradas por encima de 500 reales, tenían orígenes palermitanos teniendo en cuenta la presencia de las dos obras de Paladini ${ }^{71}$. Muy elevada era la valoración de las piezas de oro y plata existentes en la casa ${ }^{72}$, reflejando las relaciones de Martínez de Quintana con algunos plateros como Gabin de Alas ${ }^{73}$.

exenta del Niño Jesús en la escultura barroca andaluza”, Boletín de la Real Academia de Córdoba de Ciencias, Bellas Nortes y Nobles Artes, 114 (1998), pp. 43-66. Ángel PeÑa MarTín, "El peregrino del cielo. La devoción al Niño Jesús peregrino en las clausuras femeninas", en La clausura femenina en el Mundo Hispánico una fidelidad secular. Simposium (XIX edición) San Lorenzo del Escorial, 2 al 5 de septiembre, Madrid, Real Centro Universitario Escorial-María Cristina, 2011, pp. 31-48.

68 A la muerte de Isabel de Franqui las esculturas presentes en su domicilio fueron entregadas a diversas fundaciones religiosas como la iglesia de San Saturnino de Moneo, el monasterio de San Basilio de Madrid y el convento de Comendadoras de Juan de Alarcón, amén de algunos particulares, como refieren con detalle testamento y codicilos.

69 AHPM. Leg. 5006, fol. 338 vº. Luis Ordóñez.

70 AHPM. Leg. 5079, fol. 116 r. Bernardo Sánchez Sagrameña. 28 de septiembre de 1622.

71 El cuadro que reproduce el Pasmo de Sicilia se valoró por Nardi en 176 reales y el del Martirio de Santa Catalina en 200.

72 AHPM. Leg. 5006, fol. $394 \mathrm{v}^{\mathrm{o}}-400$

73 Archivo de la Real Chancillería de Valladolid. Registro de Ejecutorias, Caja 2003,45. 


\section{El retablo de San Saturnino en Moneo. Ejecución y traza}

Siete años más tarde de la muerte del secretario, en 1635, como ya hemos subrayado, será el pintor italiano Angelo Nardi ${ }^{74}$ quien se ocupe de realizar la valoración de las imágenes y pinturas que Isabel de Franqui remitiría a la iglesia de San Saturnino de Moneo, obras de su propiedad que reconocemos en el análisis del inventario del año 1628. En primer lugar, se hace referencia a la escultura de la Inmaculada Concepción "de bara y media de alto con sus rayos y peana dorados y la corona de estrellas y piedras de bronce dorado"75 (fig. 4).

A continuación, Nardi lleva a cabo la valoración de "dos figuras de medio bulto" de San Felipe Neri y Santa Teresa de Jesús, tasadas en 500 reales y en 660 reales respectivamente, cantidad que difiere notablemente de los 300 y 150 reales que subrayó Antonio de Herrera. Esta nueva tasación en relación con estas dos figuras nos permite reconocer algún dato novedoso pues indica que la figura de Santa Teresa está ya dorada y policromada, frente a su situación en 1628 en la que se refleja que la madera no está pintada, hecho que indicaría una fecha próxima de labrado de la imagen por parte del escultor ${ }^{76}$. Por último, Angelo Nardi nos da noticia de un Cristo crucificado de bronce con la cruz de ébano y elementos decorativos en plata, valorado en 400 reales. Junto a estas cuatro piezas el pintor de cámara llevará a cabo la tasación de dos pinturas incluidas en este lote y también procedentes de los bienes personales del matrimonio: un cuadro con el argumento de la Muerte de Santa Catalina de Alejandría y una copia del cuadro de Rafael Caída en el Camino del Calvario, conocido como el "Pasmo de Sicilia", obras firmadas por Filippo Paladini en 1598, con una valoración individual de 400 reales, mayor que la efectuada en $16288^{77}$.

La lectura detallada del testamento de Isabel de Franqui nos proporciona nuevos datos relativos a estas piezas y a su traslado a Moneo, la donación de otros objetos de gran valor para la iglesia ${ }^{78}$, así como nos aproxima al conocimiento de la autoría de las imágenes tasadas por Nardi, que no aparece indicada en el inventario y documento de tasación analizados. En uno de los capítulos de este documento, al hablar de la elaboración de un retablo para el presbiterio de la iglesia de San Saturnino, Isabel de Franqui refiere que Antonio de Herrera Barnuevo había realizado por encargo suyo una escultura de San Saturnino "de madera de bulto"79 policromada por Martín Ortega (fig. 5). La presencia certificada de Antonio de Herrera Barnuevo en la realización de esta imagen dedicada al titular de la parroquia así como la relación previa ya señalada de este escultor con el matrimonio, nos aproxima a su personalidad artística en la realización de las imágenes de la Inmaculada Concepción, San Felipe Neri y Santa Teresa que analizaremos con detalle más adelante, así como a su muy probable intervención en la definición de las trazas del retablo en que se encuentran, trabajo realizado por artífices de la diócesis burgalesa conforme a un modelo enviado por la promotora desde Madrid, que dejará reflejado su linaje en un blasón superior ${ }^{80}$.

${ }^{74}$ La labor como tasador de obras de arte por parte de Angelo Nardi aparece recogida en BURKE y CHERRY, 1997, p. 1623.

75 AGDBu. Moneo. Leg. 10, s/f. Tasación de ornamentos. Madrid, 29 de marzo de 1635.

76 AGDBu. Moneo. Leg. 10, s/f. Tasación de ornamentos. Madrid, 29 de marzo de 1635.

77 CAdiÑAnos BARDECÍ, 2005, p. 49.

78 Ofrece una lámpara de plata valorada en 100 ducados y, tras su fallecimiento, pide que se entregue un cáliz y patena que tenía en el oratorio. Asimismo, dona un Niño Jesús vestido de cardenal, un cuadro de Santa Ana, otro de Nuestra Señora de Itria, advocación milagrosa destacada en Sicilia que representa una imagen de la Virgen hodegetria, un cuadro de gran tamaño de Cristo crucificado, otra pintura de San Bartolomé y una pequeña tabla con el tema de Nuestra Señora de la Leche, calificado como antiguo.

79 AHPM. Leg. 6581, fol. $602 \mathrm{v}^{\mathrm{o}}$. Martín Ortega era colaborador de Antonio de Herrera Barnuevo con el que ajusta el día 10 de agosto de 1626 sus cuentas por varios trabajos, como la elaboración de un retablo y custodia en la iglesia de Vallecas en los que también intervinieron Angelo Nardi, Francisco Granelo, Luis Fernández y Francisco Esteban. Ver el artículo de Antonio José DíAz FERNÁNDEZ, "El retablo mayor de la parroquial de Vallecas (Madrid): una arquitectura desaparecida de Pedro y Francisco de la Torre (1672)", Espacio, Tiempo y Forma. Serie VII. Historia del Arte, 17 (2004), p. 152.

80 En él aparecen tres coronas bajo una cruz, propio del linaje italiano Franchi. 


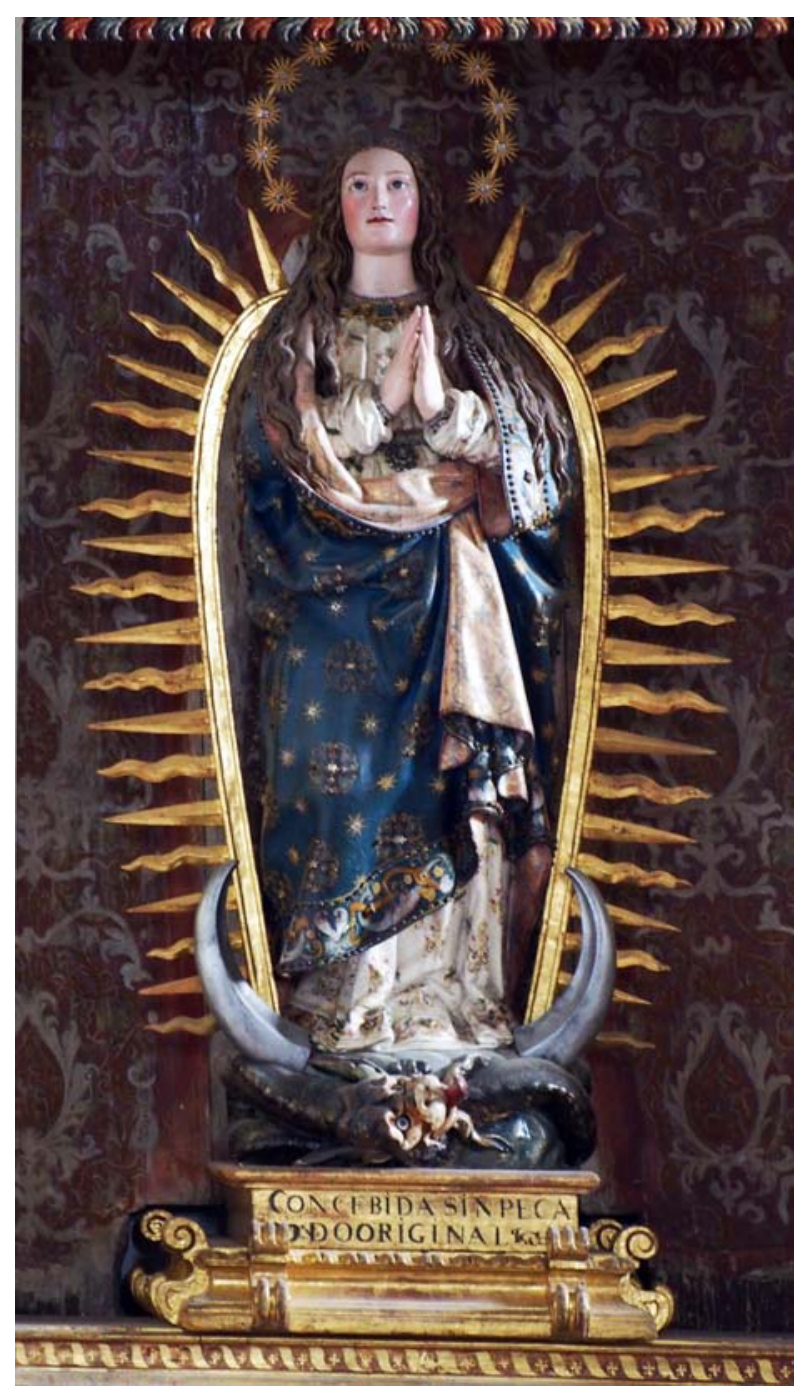

Fig. 4. Antonio de Herrera. Inmaculada. Retablo mayor de Moneo (Burgos).

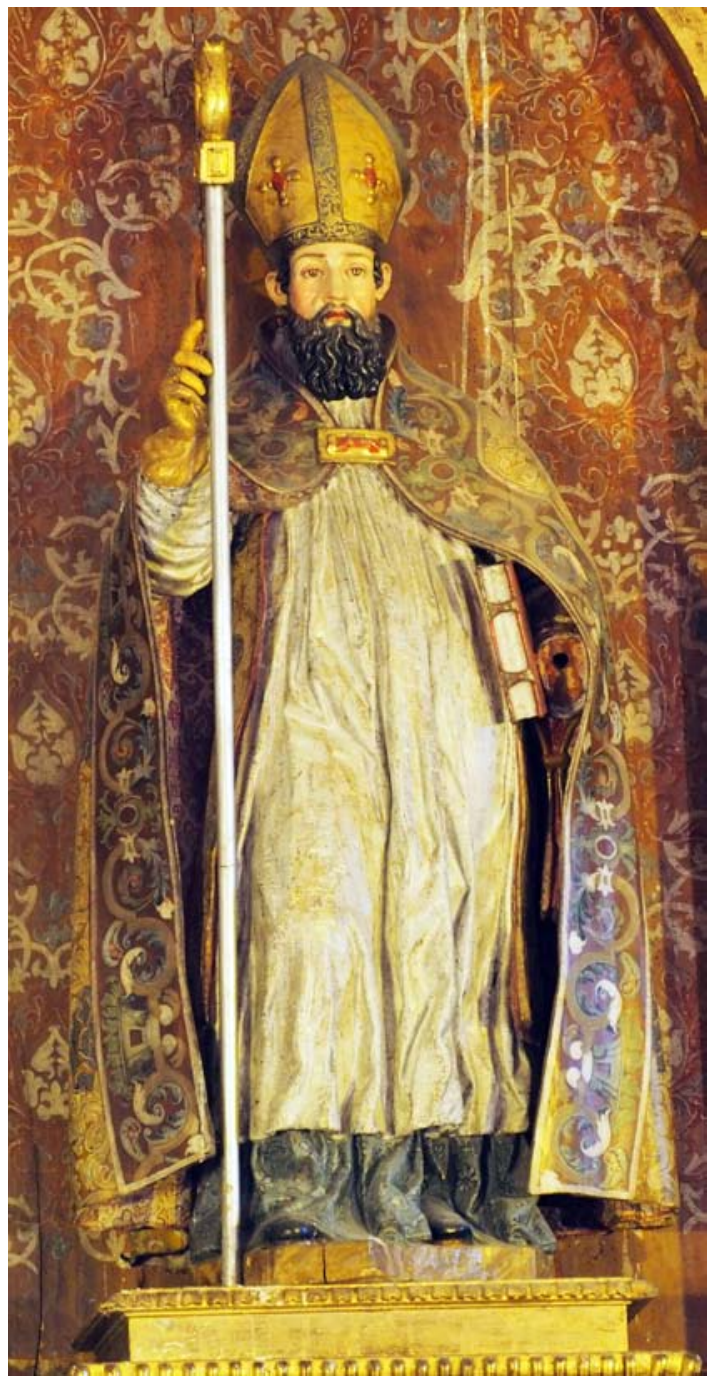

Fig. 5. Antonio de Herrera. San Saturnino. Retablo mayor de Moneo (Burgos).

Un documento notarial firmado ante el escribano Alejo de Ceballos de la localidad de Medina de Pomar el día 4 de octubre de 1638, incorpora las condiciones ${ }^{81}$ dadas en 1636 ante Isabel de Franqui, que delegará todos los asuntos relativos a la construcción del retablo en manos de Lucas Ibáñez Ibargüen ${ }^{82}$. En ellas y en la traza dibujada del retablo se subraya que la arquitectura se habrá de hacer en madera seca. Por lo que respecta al diseño se indica su estructura y formato, subrayándose que contará con un pedestal en el que se practicarán dos hornacinas laterales para disponer las esculturas de San Felipe Neri y Santa Teresa, realizándose en el centro una "caxa con su arquete e imposta moldurada" para el sagrario. El cuerpo principal debía ser de orden corintio, con cuatro columnas redondas, y tres calles, situándose en el centro una caja "quadrada con su moldura tallada moldada como lo muestra la traça que es donde sse a de poner la

81 AGDBu. Leg. 10, s/f. Obra del retablo para la iglesia de San Saturnino de Moneo.

82 En 1640 aparece en la documentación correspondiente del Hospital de la Concepción aceptando la curaduría de su sobrina Josefa de Porras Salazar. 
imagen de la limpia conçepcion de nuestra señora", con una altura de seis pies y un cuarto, y flanqueada por los dos cuadros de pintura. El segundo cuerpo se llevará a término con columnas de orden compuesto y en él se situará una "caxa quadrada" para la escultura de San Saturnino.

El pliego de condiciones también señala los rasgos de la coronación del retablo, con "sus contrafuertes o pirámides", y además hace referencia a su dorado, con el emparejado y embolado, así como el bruñido del oro y el estofado de los respaldos de las cajas. Desconocemos la autoría de la traza presentada por Isabel de Franqui para el retablo de la iglesia de Moneo pero creemos que ha de ser obra de Antonio de Herrera Barnuevo que, además de su trabajo como escultor, elaboró trazas y condiciones para la ejecución de retablos ${ }^{83}$. El análisis de las condiciones elaboradas por este imaginero para otros contratos, como la obra del retablo promovido por el capitán Gabriel de Rojas Páramo fechada en 3 de agosto de $1615^{84}$, reflejan evidentes puntos de contacto con el ejemplar burgalés, al disponer un primer cuerpo "de horden corintia con quatro colunas entorchadas y el segundo, de la orden conposita", incorporando hornacinas para las esculturas y blasones en los extremos superiores de la arquitectura.

Para la ejecución de esta obra se hará un pliego de remate en la localidad de Medina de Pomar el 24 de octubre de 1638 al que, dado el interés del proyecto, se presentarán diferentes artífices que hicieron diversas pujas a la baja. Bartolomé López de Frías, vecino de Villapanillo en la Merindad de Cuesta Urria, lo presupuestará inicialmente en 4.400 reales. Posteriormente, Lucas Ruiz Isla ofrecería hacerlo por precio de 4.000 reales. Este mismo artífice señalará varias bajas desde 3.000 reales a 2.652. Otros artífices presentes en la puja fueron Pedro Gutiérrez, vecino de Barruelo, que ofrecería hacerlo en 700 ducados y 200 reales, el vecino de Trespaderne Juan Gil de Celada que hará diversos ajustes desde 3.000 reales a 2.662, y finalmente Juan López de Frías en quien se remataría por precio de 2.566 reales $^{85}$.

Si por lo que respecta a la arquitectura, este remate no nos deja claro quién realizó el diseño traído desde la Corte, aunque muy probablemente fue Herrera, sí están documentados trabajando en 1647 diversos artífices en labores de arquitectura y escultura. El dorado y policromado de la estructura en madera se llevará a cabo un tiempo más tarde. Una de las mandas de un codicilo de Isabel de Franqui, firmado el 12 de enero de 1653, señala que no se había acabado el dorado del retablo, debiendo ocuparse de ello su sobrino Andrés Carrillo y Aragón ${ }^{86}$.

Habrá que esperar hasta 1663 para que se lleve a cabo el concierto de dorado y estofado del retablo, así como la realización de las pinturas de los entrepaños, obra de Gregorio Gómez de Huidobro y Francisco Martínez de Losa vecinos de Medina de Pomar, que efectuarán el trabajo por la cantidad de 4.864 reales, siendo sufragada la obra por Juan de Arroyo, que finalizará el trabajo iniciado por Isabel de Franqui ${ }^{87}$.

83 En el haber de Antonio de Herrera hemos de señalar, entre otros, la factura de un retablo para el capitán Gabriel de Rojas el año de 1615, un retablo para Mariana de Rojas en el que trabajó junto a Ginés Carbonel, y el de la Concepción, promovido por Cristóbal de Medina, tesorero de las alcabalas, en 1628.

84 AHPM. Leg. 1867, fols. 1.057 r - 1.060 vº . Esteban Liaño. Contrato de obra de Antonio de Herrera Barnuevo para el capitán Gabriel de Rojas Páramo. 3 de agosto de 1615.

85 AGDBu. Moneo, Leg. 10, s/f. En dicho documento se subraya que se ha rematado en Juan López de Frías la obra del retablo como "el mas baxo postor".

86 AHPM. Leg. 6528, fol. 602 vº. Antonio Cadenas. 12 de enero de 1653. Codicilo de Isabel de Franqui. Andrés Carrillo y Aragón, hijo de Plácido Carrillo, ingresará en 1651 la Orden de Calatrava. Archivo Histórico Nacional, Consejo de Órdenes (España). OM-CABALLEROS_CALATRAVA, Exp.500. Pruebas para la concesión del título de Caballero de la Orden de Calatrava de Andrés Carrillo y Bolonia Muzo y Belader, natural de Palermo. Como señala Antonio de Mendoza en su obra Discursos de Antonio de Mendoza Secretario de Cámara de Felipe IV, Isabel de Franqui le apoyará con abundantes cantidades de dinero.

87 Cadiñanos Bardecí, 2005, p. 50. 


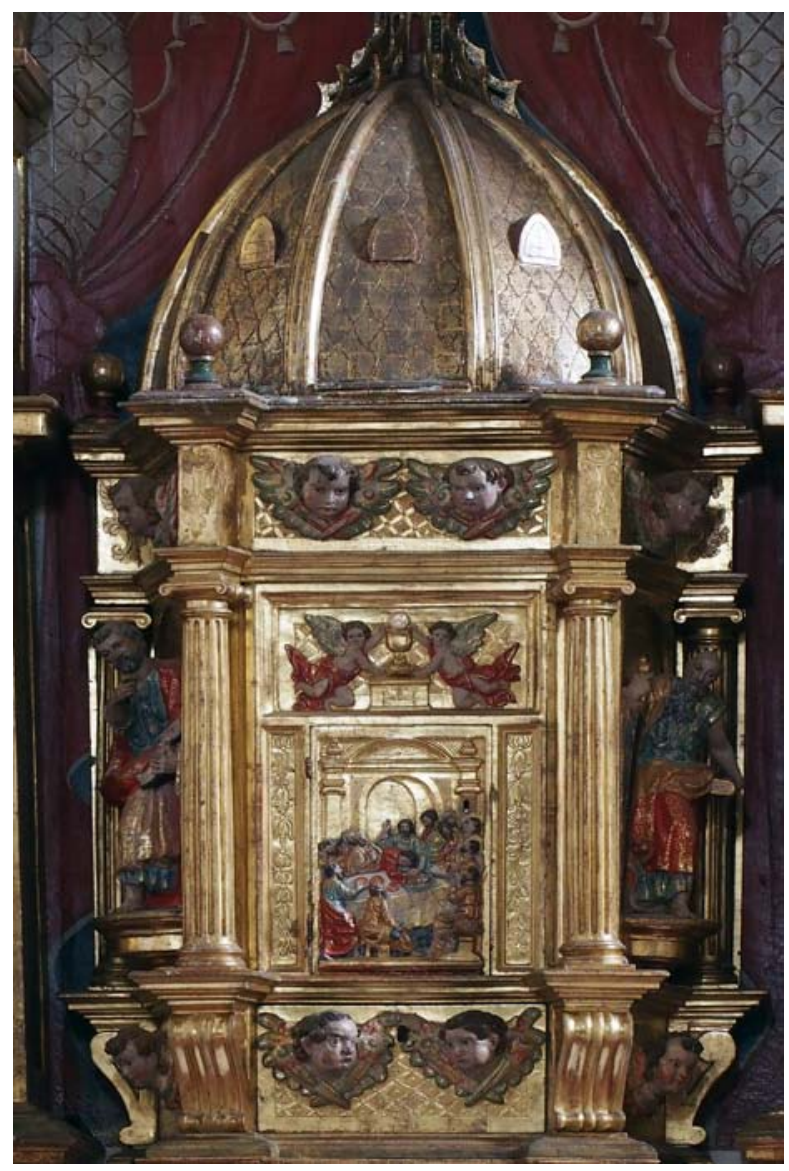

Fig. 6. Bartolomé Angulo. Sagrario. 1577. Retablo mayor de Moneo (Burgos).
Sobre un sotobanco de finales del siglo XVIII ${ }^{88}$ que elevó la altura del retablo en esa fecha, se levanta el banco en cuyo centro se ubica el tabernáculo ${ }^{89}$ ejecutado en 1577 por el ensamblador Bartolomé de Angulo y el pintor dorador Juan de la Concha ${ }^{90}$ (fig. 6). En dos nichos laterales se ubican las antedichas tallas de medio cuerpo de Santa Teresa y San Felipe Neri y los netos que sustentan las columnas, pintados por Gregorio Gómez de Huidobro y Francisco Martínez de Losa, que presentan imágenes de cuerpo entero de escasa calidad con las representaciones de San Jerónimo, Santo Tomás, San Gregorio, San Agustín, San Mateo, San Marcos, San Juan y San Cristóbal. Cuatro columnas corintias de tercio inferior tallado con elementos vegetales y los dos superiores estriados articulan el cuerpo principal del retablo en cuyo centro aparece la ya citada escultura de la Inmaculada y en las calles laterales los lienzos del Camino del Calvario y el martirio de Santa Catalina de Alejandría de Filippo Paladini. Por encima del entablamento, cuyo friso aparece ornado con una decoración de roleos vegetales, aparece un cuerpo de remate flanqueado por columnas corintias. En el centro se ubica un nicho de remate semicircular en el que se coloca la talla de San Saturnino y en cuya zona superior se dispone un frontón triangular con jarrones en sus derrames. Los aletones laterales presentan las armas de Isabel de Franqui y Juan de Arroyo.

\section{Las pinturas del retablo}

Como hemos señalado, el retablo presenta en sus calles laterales dos grandes lienzos de orígenes palermitanos que representan una copia del cuadro conocido como el "Pasmo de Sicilia" (fig. 7) y el tema del martirio de Santa Catalina (fig. 8), que están firmados por Filippo Paladini en $1598^{91}$. Este maestro nació en Casi Val di Sieve (Toscana) en 1544. Tras unos problemas con la justicia y habiendo pasado por Malta, donde se documenta obra suya, se trasladó a Sicilia desarrollando una notable actividad pictórica en el tránsito entre el siglo XVI y XVII ${ }^{92}$. Formado en el tardomanierismo florentino, muestra un estilo característico definido por

\footnotetext{
88 Puede que estas obras se llevaran a cabo a raíz de los trabajos que se verificaron en la iglesia en 1769. AGDBu. Moneo. Libro de Fábrica 1755-1814. Cuentas de 1769.

89 De formas tardorrenacentistas y con remate cupuliforme presenta un relieve de la Última Cena en la puerta del sagrario y dos pequeñas tallas de bulto de San Pedro y San Pablo labradas en escorzo para que puedan ser vistos desde el frente.

90 AGDBu. Leg. 10, 21 de octubre de 1577. Escritura del relicario de la villa, Escritura ante Marcos Martínez de Quintana, escribano de su majestad. Diego López contrata con Bartolomé Angulo escultor vecino de Valpuesta y Juan de la Concha, pintor, vecino de Medina de Pomar, la hechura del relicario.

91 Aparece la firma Piliph. Palatin. Op. ann. 1598. Igualmente aparece la forma $R$. Urbinas, que hace referencia al pintor que ejecutó la pintura de los olivetanos.

92 Gioacchino DI MARzo, "Di Filippo Paladini pittore fiorentino della fine del secolo XVI e de primordi del XVII", Archivio storico italiano, s. 4, IX (1882), pp. 174-197; Sergio Troiso, Filippo Paladini un manierista fiorentino in Sicilia, Palermo, Editorial Ariete, 1997.
} 
sus formas nerviosas, con figuras estilizadas y afiladas y complejas composiciones escenográficas ${ }^{93}$. En algunas de sus obras se detectan unos ciertos ecos del claroscurismo caravagiesco. Murió en Mazarino (Sicilia) en 1614 tras una productiva vida artística ${ }^{94}$.

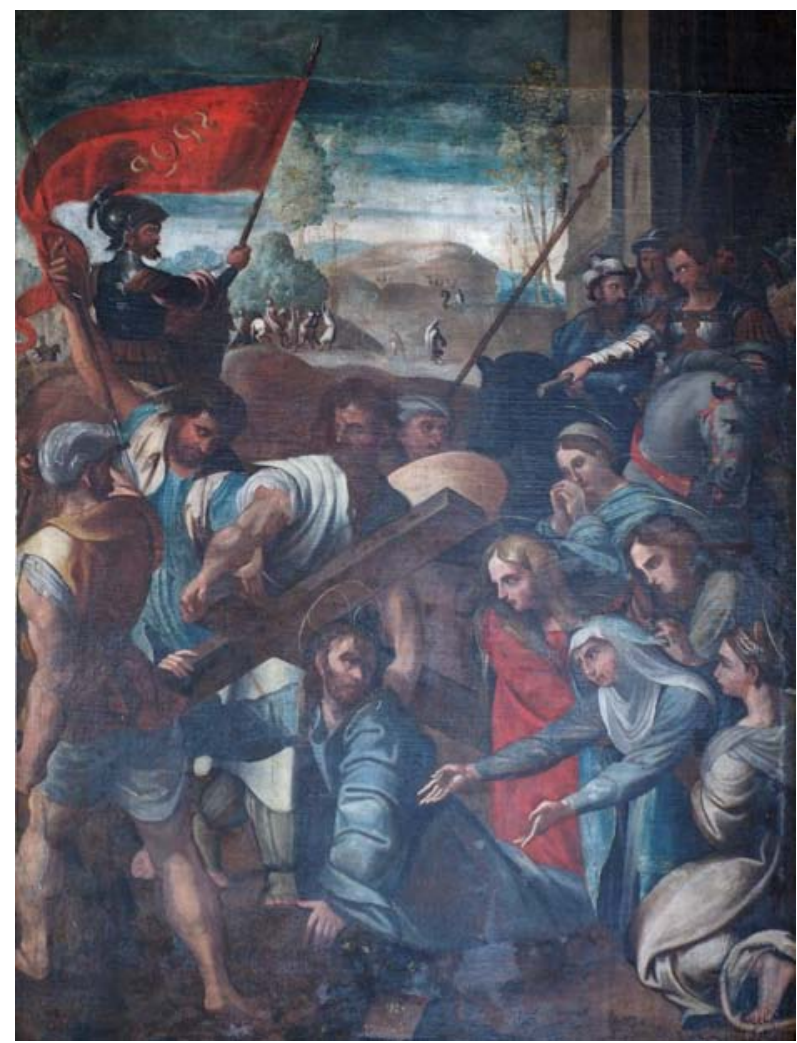

Fig. 7. Filippo Paladini. Camino del Calvario, copia del "Pasmo de Sicilia". 1598. Retablo mayor de Moneo (Burgos).

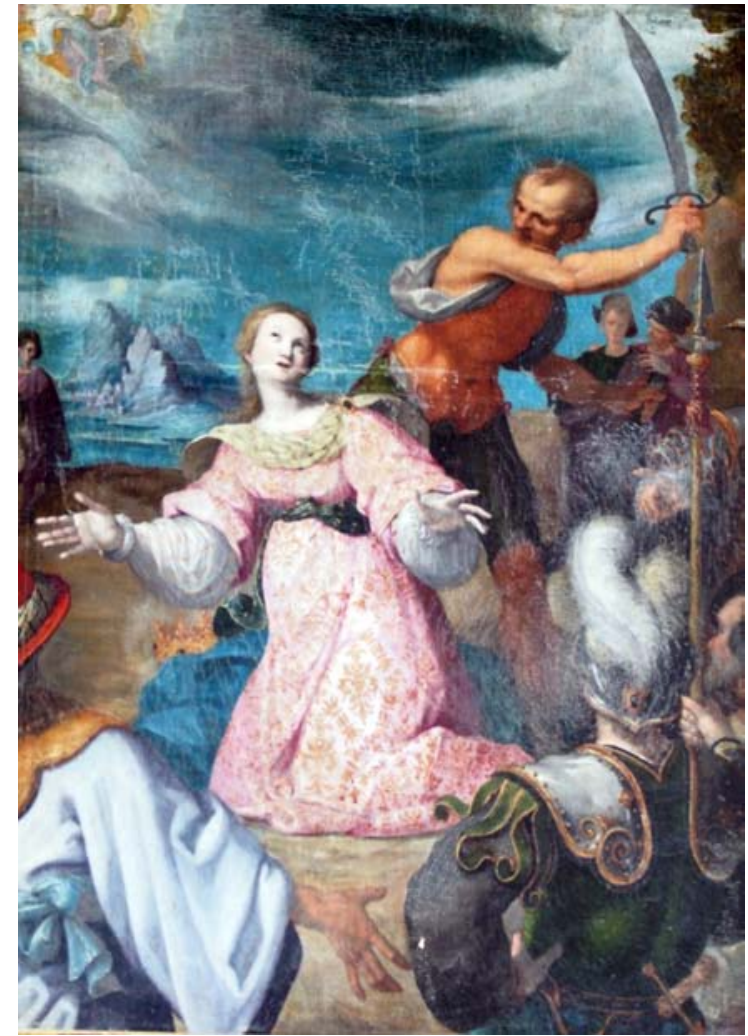

Fig. 8. Filippo Paladini. Martirio de Santa Catalina. 1598. Retablo mayor de Moneo (Burgos).

En relación al Camino del Calvario, reproduce de forma mimética la composición que Rafael de Urbino pintó hacia 1515 para presidir el convento de los olivetanos de Palermo por encargo del Giovanni Basilico. $\mathrm{Su}$ nombre se vincula al convento Santa Maria dello Spasimo (Santa María de la Angustias), dando lugar en español al nombre del "Pasmo de Sicilia". Muy pronto esta obra adquirió fama internacional"5 y de ella se hicieron múltiples copias algunas de ellas en la propia isla de Sicilia ${ }^{96}$. La fama del "Pasmo" llegó pronto a España donde se conocen algunas copias tempranas del cuadro ${ }^{97}$. Sin duda, Paladini copiaría el cuadro en su emplazamiento primitivo, aunque el autor ejecutó un trabajo que aun manteniendo la composi-

93 Paolo Russo, Un genio vagante... in giro nella Sicilia. Filippo Paladini e la pittura della tarda maniera nella Sicilia centrale, Caltanissetta, Lusografica, 2012; Paolo Russo y Vittorio VICARI, Filippo Paladini e la cultura figurativa nella Sicilia centro meridionale tra cinque e seicento, Caltanissetta, Lusografica, 2007.

94 Cesare Brand, Catalogo della Mostra di Filippo Paladini, Palermo, Assemblea Regionale Siciliana, 1967.

95 Vasari llegó a señalar de esta obra que en Sicilia era más famosa que el Etna. Giorgio VASARI, Le vite de' piu eccellenti pittori, scultori, e architettori... Apresso i Giunti, Florencia, 1568, t. II, p. 79.

96 Así Giovan Paolo Fonduli en 1574 hizo una copia conservada en la iglesia de Santo Domenicho de Castelvetrano (Trapani) y Giuseppe Salerno hizo otra para la iglesia del Salvador para la iglesia de Gangi (Palermo). Teresa PugliatTi, Pittura della tarda Maniera nella Sicillia occidentale 1557-1647), Palermo, Kalós, 2001, pp. 69 y 397.

97 José María Ruiz Manero, Pintura italiana del siglo XVI en España. T.II. Rafael y su Escuela, Madrid, Fundación Universitaria Española, 1996, pp. 61-68. 
ción y el cromatismo del original presenta unos rasgos más toscos debido a la aparición de los característicos perfiles angulosos de las figuras empleados por Paladini.

El Martirio de Santa Catalina es una obra gemela en tamaño a la anterior. Con una visión perspectiva baja, en un primer plano aparecen las figuras de soldados y personajes que asisten al martirio y que quedan representados de medio cuerpo de un modo semejante a como se les representa en el lienzo del Martirio de Santa Águeda que este maestro pintó para la catedral de Catania. En un segundo plano y centrando la escena, se sitúa la santa arrodillada que se dispone a morir con una pose teatral que se continúa en la figura del verdugo que porta en su mano derecha la espada con la que va a decapitar a Santa Catalina desarrollando un violento contrapposto. La mártir viste una túnica rosácea ${ }^{98}$ y su rostro queda resaltado lumínicamente ${ }^{99}$. En el fondo se sitúan otros personajes que observan la escena y se abre un paisaje marítimo y rocoso con un rompimiento de cielo con representaciones de angelitos que se preparan a recibir el alma de la mártir. En conjunto, este lienzo presenta una mejor calidad que el del "Pasmo". Ambas obras serían encargadas en Palermo por el matrimonio Martínez de Quintana-de Franqui, con bastante probabilidad. La primera pintura sería admirada por el Secretario y su esposa y la segunda respondería a las devociones propias de ambos personajes y por ello decidirían encargárselas a Paladini que en los años finales del siglo XVI era una de las figuras de referencia en la pintura siciliana.

\section{Las esculturas del retablo mayor de la iglesia de San Saturnino de Moneo y la obra de Antonio de Herrera Barnuevo}

Además de las esculturas que conforman el sagrario, ejecutadas como señalamos en 1577, la iconografía escultórica se desarrolla a través de las representaciones de las tallas enteras de bulto de la Inmaculada, San Saturnino y de los relicarios de medio cuerpo de Santa Teresa y San Felipe Neri. Aunque solamente tenemos certeza documental absoluta de que fue Antonio de Herrera el autor de la talla de San Saturnino, no nos cabe ninguna duda de que fue este escultor quien talló todo el conjunto. Además de las relaciones que tuvo este maestro con el matrimonio Martínez de Quintana-de Franqui, lo que nos ratificaría en esta autoría, existen notables relaciones estilísticas entre las tallas de Moneo y otras obras del escultor real.

Antonio de Herrera fue uno de los escultores más destacados del panorama madrileño, documentándose su producción entre 1607 y 1647. Formado en la tradición tardoescurialense, pronto comenzaría a caminar hacia la estética del naturalismo barroco, llegando en algunas obras a detectarse un cierto, aunque matizado, influjo de Gregorio Fernández. Su prestigio le llevaría a alcanzar el cargo de escultor real en 1623 y, en 1635, de aparejador real. Desarrollaría una importante labor como escultor religioso, pero también ejecutaría obras de carácter profano en piedra. Estuvo involucrado en algunos grandes proyectos retablísticos (realizando trazas, ejecutando las tallas y labrando ensamblajes solo o en colaboración) como el de Getafe $^{100}$ o los desaparecidos mayor del monasterio de San Jerónimo, el labrado para Gabriel Hernández para el convento de San Francisco de Madrid ${ }^{101}$, el ejecutado para María de Escobar en la iglesia madrileña de San Justo ${ }^{102}$ o el de San Isidro en la iglesia de San Andrés de esta misma villa ${ }^{103}$.

\footnotetext{
98 Los caracteres de la tela de la túnica de Santa Catalina recuerdan los de la túnica del rey Melchor de Adoración de los Magos de la iglesia de los capuchinos de Calascibetta.

99 Este rostro presenta unos caracteres muy parecidos a los que aparecen en representaciones de Vírgenes y santas por Paladini.

100 Alfonso E. PÉrez SÁnchez, "Retablos madrileños del siglo XVII", en Retablos de la Comunidad de Madrid, Madrid, Comunidad de Madrid, 1995, pp. 215-217.

101 Mercedes Agulló CoBO, Documentos sobre escultores, entalladores y ensambladores de los siglos XVI al XVIII, Valladolid, Universidad de Valladolid, 1978, pp. 89-90

102 Mercedes Agulló CoBo, Documentos para la historia de la escultura española, Madrid, Fundación de Apoyo de la Historia del Arte Hispánico, 2005, p. 154.

103 Félix Díaz Moreno, "El antiguo retablo de San Isidro en San Andrés de Madrid, traza del escultor real Antonio de Herrera”, Anales del Instituto de Estudios Madrileños, XLVI (2006), pp. 1015-1022.
} 
Sin duda, la pieza más singular del conjunto de Moneo es la talla de la Inmaculada que preside el retablo. Esa obra fue tasada por el propio Antonio de Herrera Barnuevo ${ }^{104}$, y era muy grande la estimación que tenía de la imagen su propietaria Isabel de Franqui, quien, en un documento fechado en Madrid el día 26 de abril de 1632, señala que "en qualquiera monasterio, o Parrochia de esta corte que quisiere yo hacer mi entierro y dado que en esta corte lo mejor que abía, porque por solo una imagen de Nuestra Señora de la Concepción que yo tengo, ya digo me darían lo que yo quisiesse"105. Efectivamente, la escultura de Moneo presenta una notabilísima calidad (fig. 9). No se ha localizado el contrato de la obra pero, sin duda, fue labrada por Herrera pues se asemeja a otras tallas labradas por este escultor con esta misma representación. Con forma oval, vestida con túnica y manto que se recoge en el brazo izquierdo, presenta unos suaves plegados de talla virtuosa. Aparece con las manos en oración, aunque se rompe, como es habitual en otras tallas inmaculistas de Herrera, con la simetría al desplazarse ligeramente hacia un lado. El rostro queda dotado de una gran delicadeza y sobre sus hombros se despliegan sus largos cabellos. Se levanta sobre la imagen del diablo y un creciente lunar y se coloca sobre una peana en la que aparece la inscripción "Concebida sin pecado original". Rodea la figura una aureola de rayos solares. Desconocemos el nombre del pintor que procedió a la actuación polícroma aunque, debido a las semejanzas que presenta con la Inmaculada de la catedral de Segovia (fig. 10), quizá pudo ser el mismo maestro quien realizó estas actuaciones, ambas definidas por su virtuosismo y por el uso de elementos añadidos que contribuyen a resaltar el relieve. Destaca el magnífico tratamiento de las carnaciones.

La Inmaculada de Moneo se halla dentro de una serie de piezas creadas por este maestro que tuvieron un notable éxito y que se encuentran dentro del auge que tuvo la devoción y el culto inmaculista en la España de comienzos del siglo XVII ${ }^{106}$. En 1617, Herrera había esculpido una imagen muy semejante a la de Moneo para el convento de las Descalzas Reales por encargo regio ${ }^{107}$ que se colocó en un retablo lateral de ese centro religioso ${ }^{108}$ (fig. 11). Sabemos que este retablo e imagen fueron policromados por Vicente Carducho, cuyos trabajos fueron tasados en 12.690 reales. La hechura y madera de esta famosa Inmaculada y de su retablo fueron valoradas en 13.200 reales, debiendo considerarse una de las obras mejor pagadas del futuro escultor real ${ }^{109}$ (fig. 12). Esta pieza madrileña destaca por su notable calidad, por una delicada talla del rostro, por un cuidadoso tratamiento de los paños del manto y la túnica y por un exquisito tratamiento pictórico llevado a cabo por el que entonces era uno de los más prestigiosos pintores de la corte. La talla tuvo éxito notable y fue copiada por artistas como Sebastián Bejarano, Juan de Solís y Martín de Le Mayre en la imagen de la portada lateral del convento de mercedarias de don Juan de Alarcón ${ }^{110}$ (fig. 13). El propio Herrera en 1621 la repitió para la catedral de Segovia, encargada con motivo de la celebración del voto inmaculista de esta ciudad. El cabildo segoviano comisionó a varios de sus miembros para que se ejecutara una imagen de la Inmaculada, discutiéndose si la talla debía ejecutarse en Segovia o en Madrid, decidiéndose finalmente que se labrara en la corte. Teniendo en cuenta el enorme éxito que había alcanzado la talla de Las Descalzas no debe extrañarnos que le fuera encargada al propio Herrera colocán-

104 AGDBu. Moneo. Leg. 10, s/f. Tasación de ornamentos. Madrid, 29 de marzo de 1635.

105 AGDBu. Moneo. Leg. 10, s/f. Madrid, 26 de abril de 1632.

106 Resulta interesante que fuera precisamente en 1617 cuando se talló esa escultura coincidiendo con el breve de Paulo V que prohibía afirmar públicamente que la Virgen fue concebida en pecado. Suzanne STRATTON, "La inmaculada Concepción en el arte español", Cuadernos de Arte e Iconografía, T. I, 2 (1988), pp. 65-67.

107 La abadesa de este convento era en esos momentos Margarita de Austria, gran defensora de las ideas inmaculistas, hija de la emperatriz María que había pasado sus últimos años en este cenobio.

108 Marqués del SAltillo, "Efemérides artísticas madrileñas", Boletín de la Sociedad Española de Excursiones, primer trimestre, 52 (1948), p. 14. Sabemos que Francisco Guillamas, tesorero real, autorizó el pago de esta talla que se encontraba ubicada en un altar lateral del citado convento.

109 Alfonso E. PÉrez SÁnchez, "Pintura madrileña del siglo XVII. Addenda”, Archivo español de Arte, 95 (1976), p. 296.

110 Vicente MÉndez Hernán, "La corte: la conjunción de los barrocos áulicos y castizo", en A.R. Fernández Paradas, Escultura barroca. Nuevas lecturas desde los siglos de oro a la sociedad del conocimiento. Las historias de la escultura barroca española, Vol. III, Antequera, Exlibric, 2016, pp. 126-159. 


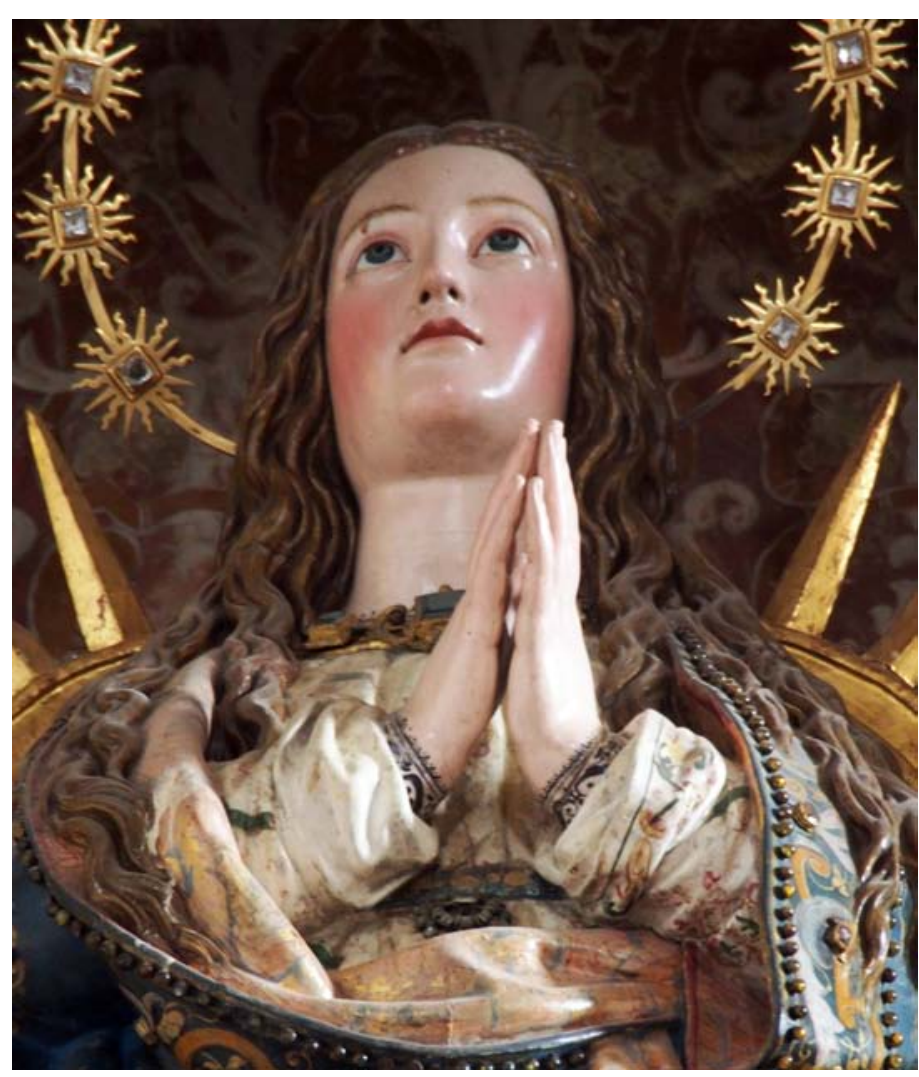

Fig. 9. Antonio de Herrera. Detalle de la Inmaculada. Retablo mayor de Moneo (Burgos).

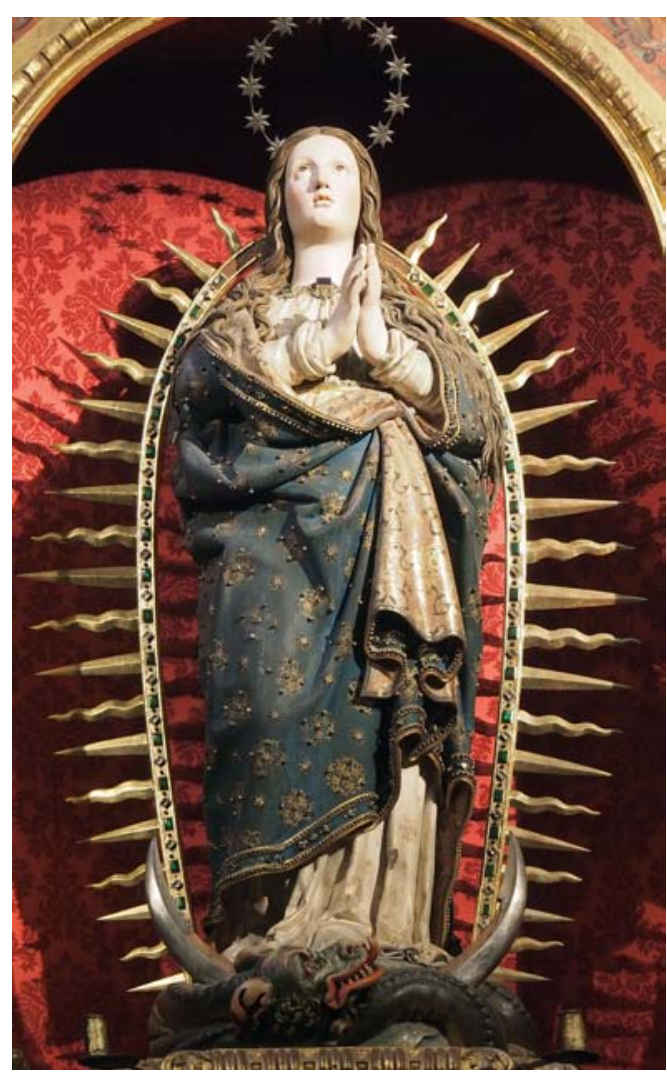

Fig. 10. Antonio de Herrera. Inmaculada. 1621. Catedral de Segovia.

dose en un sencillo retablo en el que destaca notablemente ${ }^{111}$. La Inmaculada segoviana presenta exactamentela misma composición que la madrileña, aunque muestra una mayor riqueza polícroma con elementos adventicios añadidos al manto a modo de estrellas, conservándose la aureola solar que la enmarca. Pronto la escultura segoviana tuvo un notable éxito y el escultor Felipe de Aragón la copió en 1629 ${ }^{112}$, en un estilo más tosco, con plegados alatonados que siguen la estela de Gregorio Fernández, produciéndose una síntesis entre la estética del escultor madrileño y el vallisoletano en la imagen de la iglesia de San Martín de Segovia ${ }^{113}$ (fig. 14).

Herrera creó un tipo iconográfico inmaculista que se separó del modelo triangular que difundiría Gregorio Fernández en estos años, repetido por este escultor y por muchos de sus seguidores a lo largo de

111 El 2 de enero de 1621 se comisiona a Martín Muñoz y Tomás de Molina para que vayan a Madrid y la encarguen al escultor que "hizo la de las Descalzas de aquella villa" (José Antonio Ruiz HeRnANDo, "La capilla de la Concepción de la catedral de Segovia", Estudios segovianos, XXXVII (1996), p. 655).

111 El 2 de enero de 1621 se comisiona a Martín Muñoz y Tomás de Molina para que vayan a Madrid y la encarguen al escultor que "hizo la de las Descalzas de aquella villa" (José Antonio Ruiz Hernando, "La capilla de la Concepción de la catedral de Segovia", Estudios segovianos, XXXVII (1996), p. 655).

112 Santos San Cristóbal Sebastián y Esmeralda Arnáez Pérez-Argota, La parroquia de San Martín de Segovia. Su "Historia" y su "Arte", Segovia, El Adelantado de Segovia, 1990, p. 55.

113 Felipe de Aragón y Juan Imberto son los dos más interesantes escultores seguidores de Fernández. Sin duda, la fama de la Inmaculada de la catedral le obligó a Aragón a ejecutar esta talla siguiendo su modelo, aunque no renunciaría a su formación fernandesca. Juan José MARTín GonZÁLEZ, Escultura barroca en España. 1600-1770, Madrid, Cátedra, 1983, pp. 118-119. 


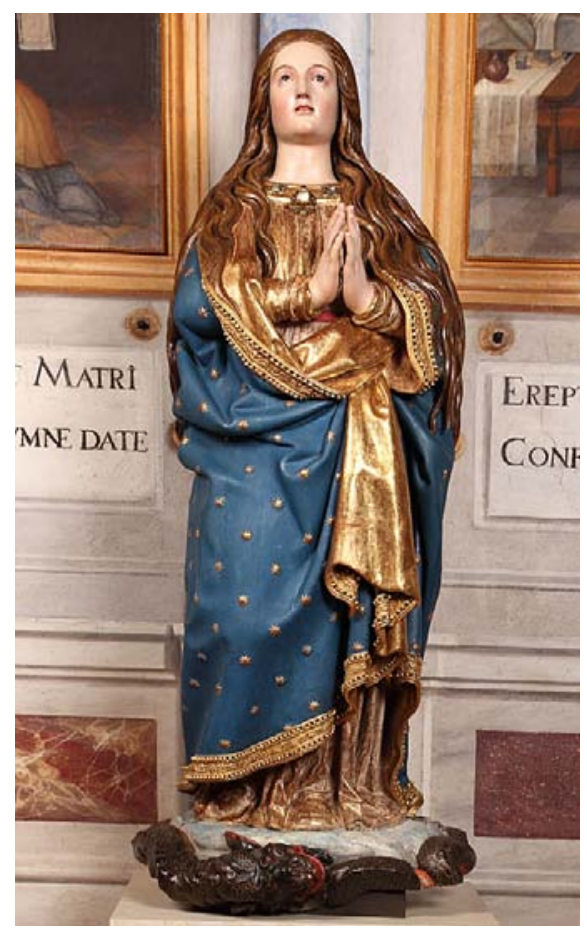

Fig. 11. Antonio de Herrera. Inmaculada. 1611. Descalzas Reales de Madrid.

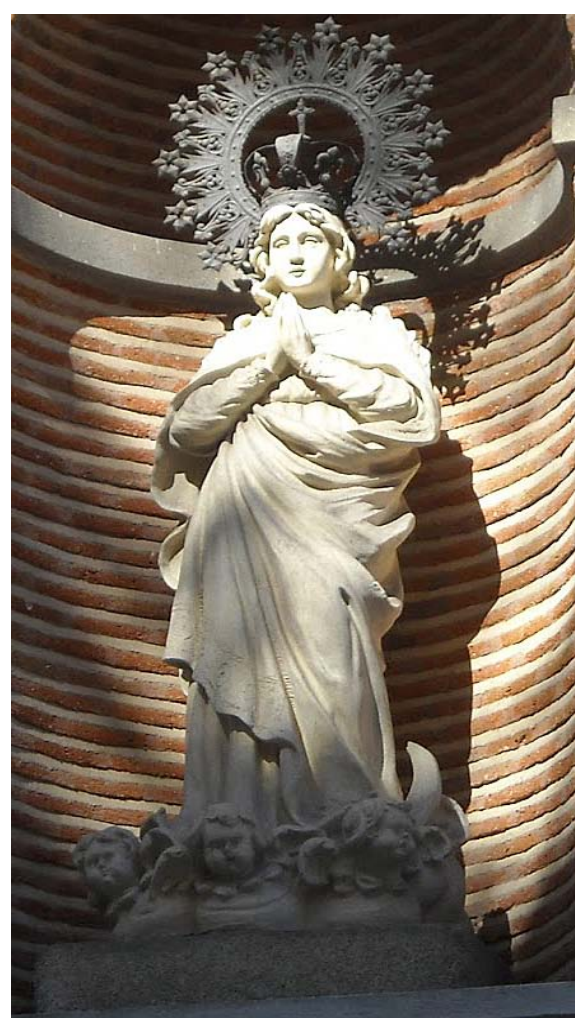

Fig. 13. Martín de Le Mayre. Inmaculada. Convento de mercedarias de don Juan de Alarcón de Madrid.

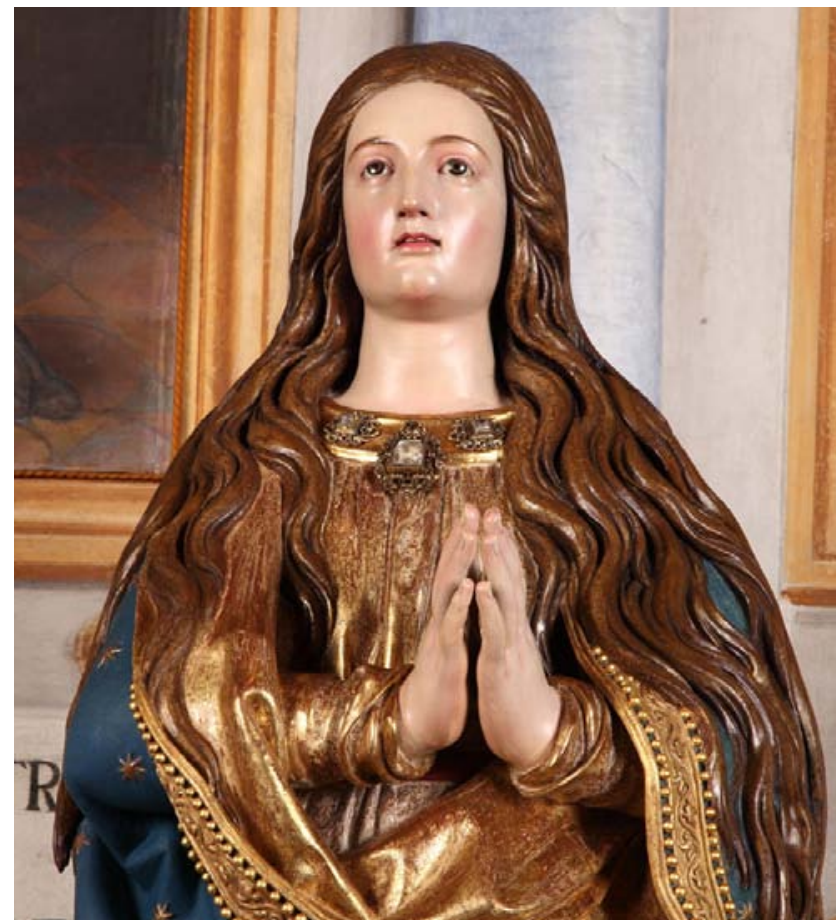

Fig. 12. Antonio de Herrera. Detalle de la Inmaculada. 1611. Descalzas Reales de Madrid.

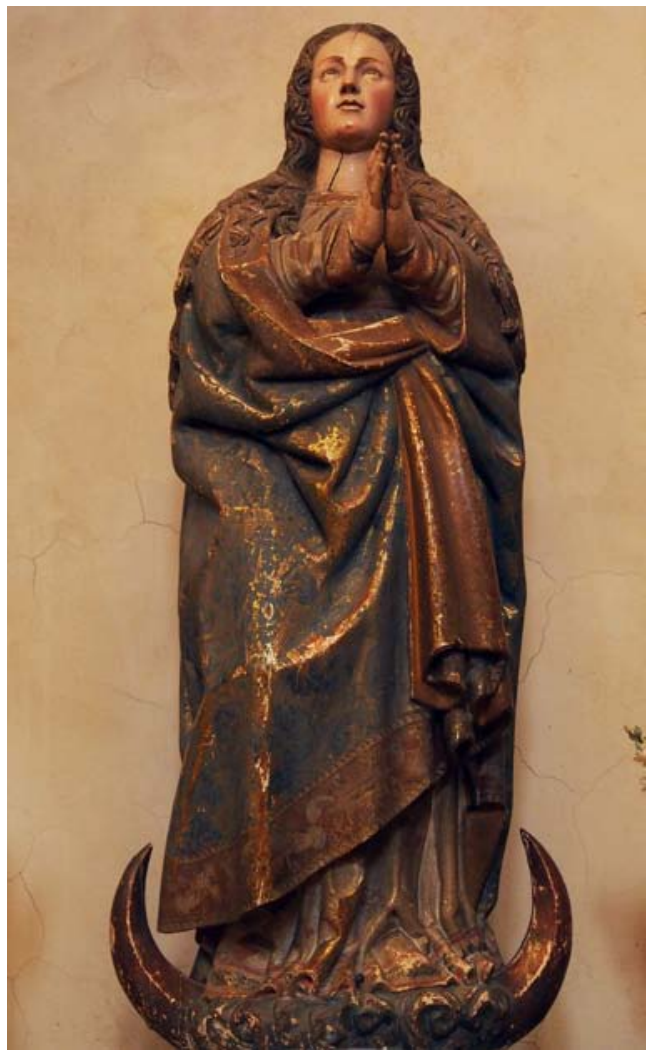

Fig. 14. Felipe de Aragón. Inmaculada. 1629. Iglesia de San Martín de Segovia. 
todo el siglo XVII ${ }^{114}$. El modelo que definirá Herrera parece estar inspirado en los grabados que, desde finales del siglo XVI, circulaban con representaciones de la Tota Pulchra ${ }^{115}$ entre los que sobresalen los de la familia Wierix en los que se rompe, en parte, con las representaciones simétricas y se colocan las manos en oración ligeramente ladeadas ${ }^{116}$. Sin embargo, creemos que la fuente gráfica más próxima a las imágenes de Herrera es el grabado que Rafael Sadeler ejecutó en $1605^{117}$ (fig. 15).

Pero no solo los grabados influirán en las tallas de Herrera. Muy probablemente, la fama de la Inmaculada de las Descalzas pudo tener su influencia en algunas láminas, como la que Pedro de Villafranca realizó en 1655 para la portada del libro Regla y establecimiento de la orden de Caballeria de Santiago de Francisco Ruiz de Vergara y Álava. Igualmente, esta obra pudo tener incidencia en las producciones calcográficas inmaculistas realizadas por Francisco Heylan en Granada en 1623 (fig. 16).

En relación a la imagen de San Saturnino no nos cabe ninguna duda de que fue labrada por Herrera ya que en el testamento de Isabel de Franqui, redactado en 1641, se señala textualmente que se enviaría a Moneo "una escultura de bulto que de presente está pintando Martín de Hortega que es San Satornino e la hizo Antonio de Herrera escultor de su magestad y se le paguen ochocientos cinquenta reales e el pintarla quatrocientos quarenta reales"118. La imagen representa al primer obispo de Tolosa vestido de pontifical, tocado con mitra. Contrasta el carácter alatonado de la capa pluvial con los nerviosos pliegues del alba blanca. Porta un libro en la mano izquierda, que hace alusión a su actividad evangelizadora, y en la derecha sujeta un báculo. Destaca el rostro barbado caracterizado por su notable solemnidad. El pintor Martín Ortega, que colaboró asiduamente con Herrera en algunas otras producciones ${ }^{119}$, realizaría la policromía. Destaca el virtuoso tratamiento de la cenefa que bordea la capa pluvial, que queda decorada con roleos vegetales, y el rostro policromado con carnaciones a pulimento.

Los relicarios de Santa Teresa y San Felipe Neri se hallan en clara relación con el auge de su devoción a raíz de sus respectivas beatificaciones y canonizaciones. Santa Teresa fue beatificada en 1614 por Pablo V y San Felipe Neri en 1615 por este mismo pontífice. Ambos fueron canonizados en 1622, por Gregorio $\mathrm{XV}$, en el mismo año que San Ignacio de Loyola, San Francisco Javier y San Isidro. Estas canonizaciones supusieron un gran acontecimiento y fueron celebradas solemnemente en España ${ }^{120}$.

No tenemos datos de índole documental que nos indiquen que los relicarios de Santa Teresa y San Felipe sean obra de Antonio de Herrera, pero su notable calidad y el hecho de que este escultor hubiera ejecutado las imágenes de la Inmaculada y San Saturnino, así como las múltiples relaciones de este maestro con la familia Martínez de Quintana-de Franqui, nos invitan a pensar que fuera este artista su ejecutor. El relicario de San Felipe Neri representa al santo de medio cuerpo, vestido con ropa sacerdotal y con los brazos cruzados sobre el pecho (fig. 17). Creemos que la fuente de inspiración de esta talla fue un grabado, ejecutado en 1595 por Alberto Ronco y realizado en Verona, que tuvo una notable difusión (fig. 18).

\footnotetext{
114 Juan José Martín González, El escultor Gregorio Fernández, Madrid, Ministerio de Cultura, 1980, pp. $224-234$.

115 Sergi DomÉnech GarcíA, "La recepción de la tradición hispánica de la Inmaculada Concepción en Nueva España: el tipo iconográfico de la Tota Pulchra", Espacio, Tiempo y Forma. Serie VII. Historia del Arte, 3 (2015), pp. 275-308.

116 STRATTON, 1998, pp. 64-65.

117 Friedrich Wilhelm Heinrich HoLlsteIn, Dutch and flemish etchings, engraving and woodcuts, ca, 1450-1700, Vol. XXII, Amsterdam, M. Hertzberger, 1988, p. 195.

118 AHPM. Leg. 6581, fol. $602 \mathrm{v}^{\mathrm{o}}$.

119 Martín Ortega era colaborador de Antonio de Herrera Barnuevo. En 10 de agosto de 1626 ajustó con él las cuentas por varios trabajos, como la elaboración de un retablo y custodia en la iglesia de Vallecas en los que también intervinieron Angelo Nardi, Francisco Granelo, Luis Fernández y Francisco Esteban. Ver el artículo de DíAZ Fernández, 2004, p. 152.

120 Miguel DE LEÓn, Fiestas de Madrid, celebradas a XIX de Junio de 1622 años, en la canonización de San Isidro, S. Ignacio, S. Francisco Xavier, S. Felipe Neri Clérigo Presbitero Florentino, y santa Teresa de Iesús, Madrid, 1622.
} 


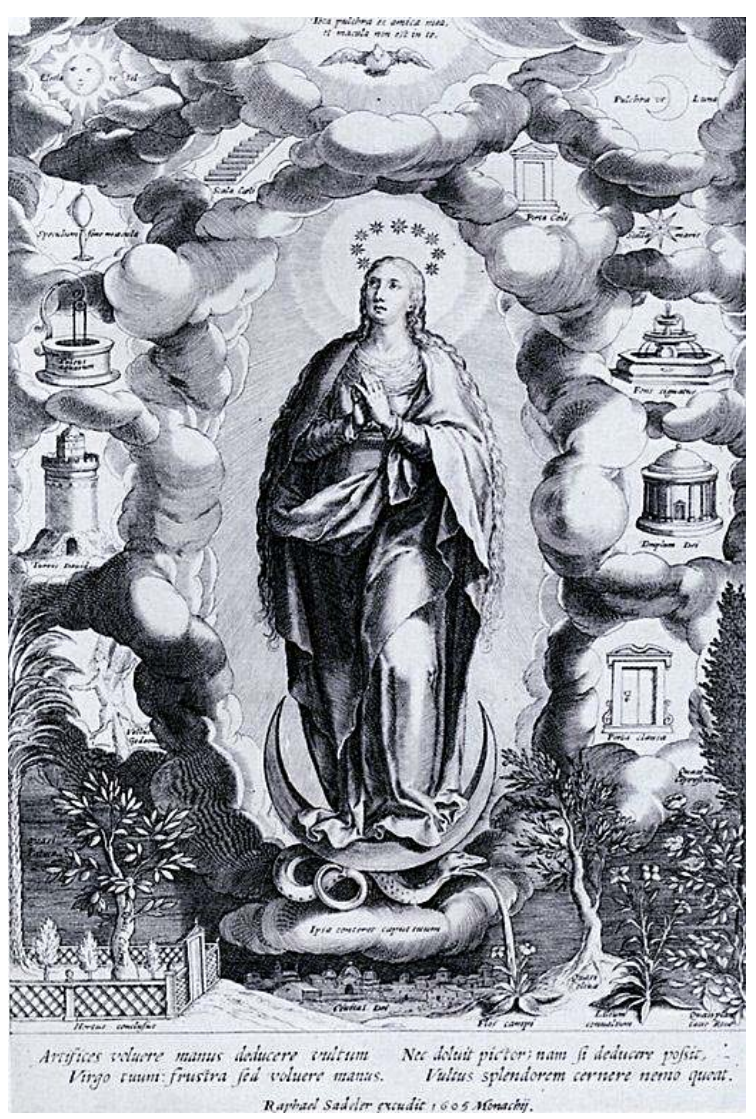

Fig. 15. Rafael Sadeler. Inmaculada. 1605.

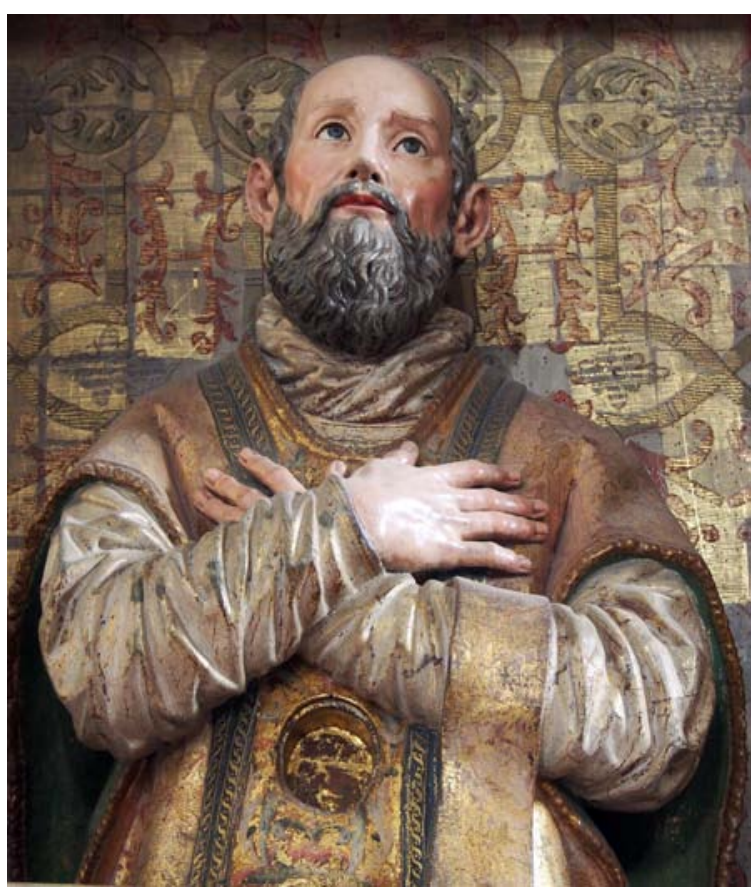

Fig. 17. Antonio de Herrera. Relicario de San Felipe Neri. Retablo mayor de Moneo (Burgos).

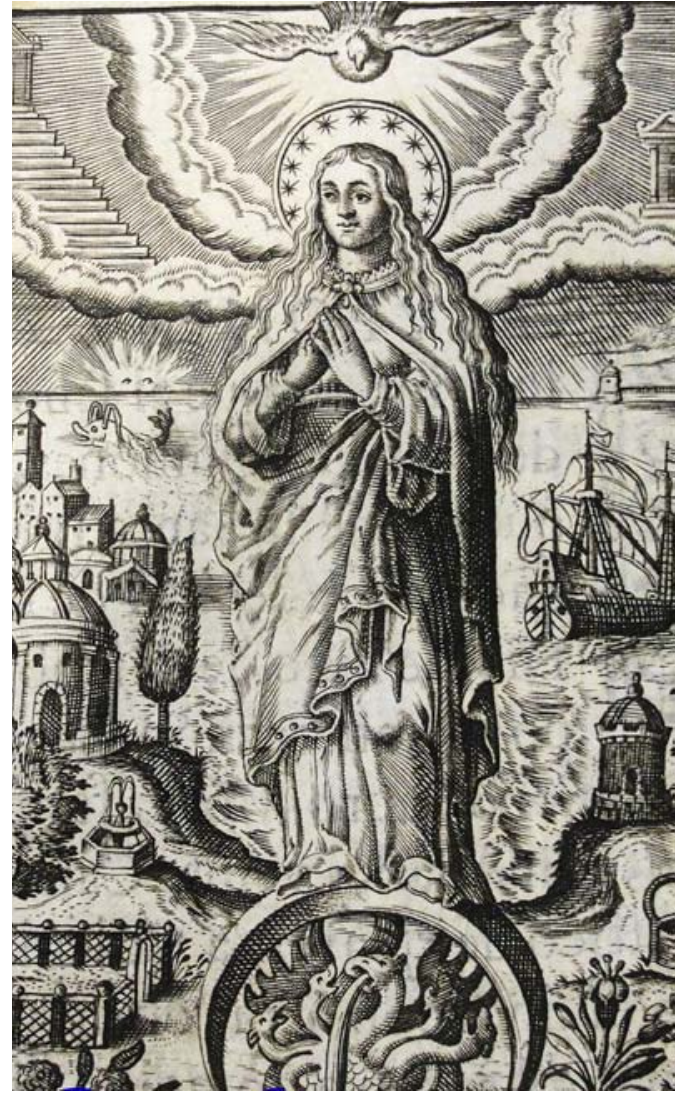

Fig. 16. Francisco Heylan. Inmaculada. 1623.

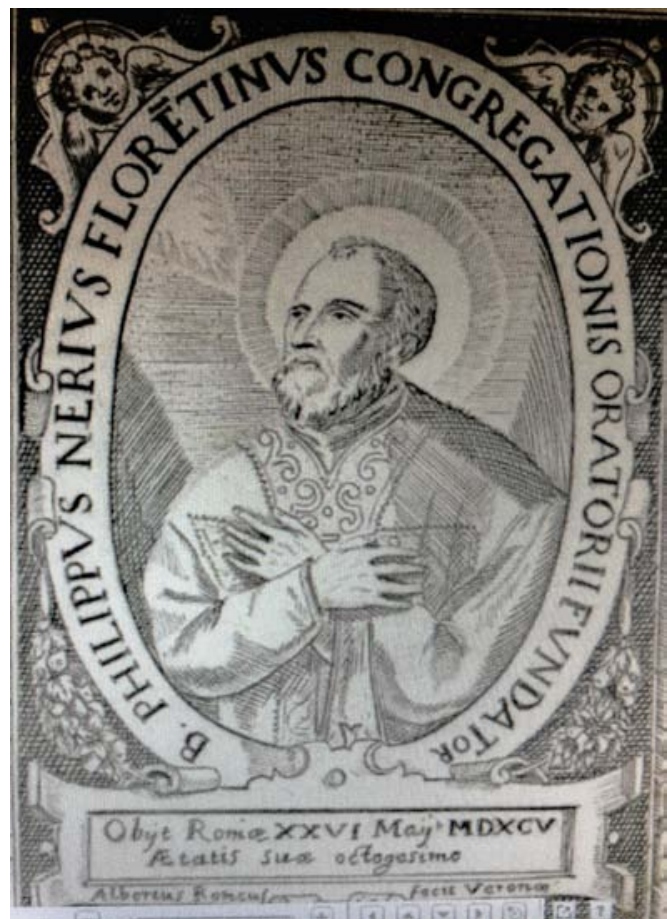

Fig. 18. Alberto Ronco. San Felipe Neri. 1595. 
El relicario de Santa Teresa, muy probablemente ejecutado por Herrera, es igualmente una obra de medio cuerpo, de notable calidad, que muestra a la santa como escritora. Viste hábito carmelitano, profusamente estofado, portando un libro en la mano izquierda y una pluma en la derecha. El rostro se sitúa ligeramente ladeado, mirando al cielo, recibiendo la inspiración divina. Desde que fray Juan de la Miseria realizara el retrato de la santa fue habitual representarla de medio cuerpo. En escultura este tipo de piezas se multiplicaron a partir de su beatificación y canonización, siendo muy frecuente que estas obras tomaran como modelo esculturas labradas por Gregorio Fernández como las que realizó para el convento de Nuestra Señora del Carmen Extramuros de Valladolid, la del Museo Nacional de Escultura (procedente del Convento del Carmen Descalzo de Valladolid) o la de la iglesia de San Antonio de Vitoria, entre otras ${ }^{121}$. La obra de Moneo se diferencia de los modelos fernandescos en que presenta unos rasgos más suaves tanto en el tratamiento de los paños como en el del rostros. Por otro lado, presenta semejanzas con algunas tallas de medio cuerpo que fueron muy habituales en esta época con representaciones de esta reformadora ${ }^{122}$ (fig. 19).

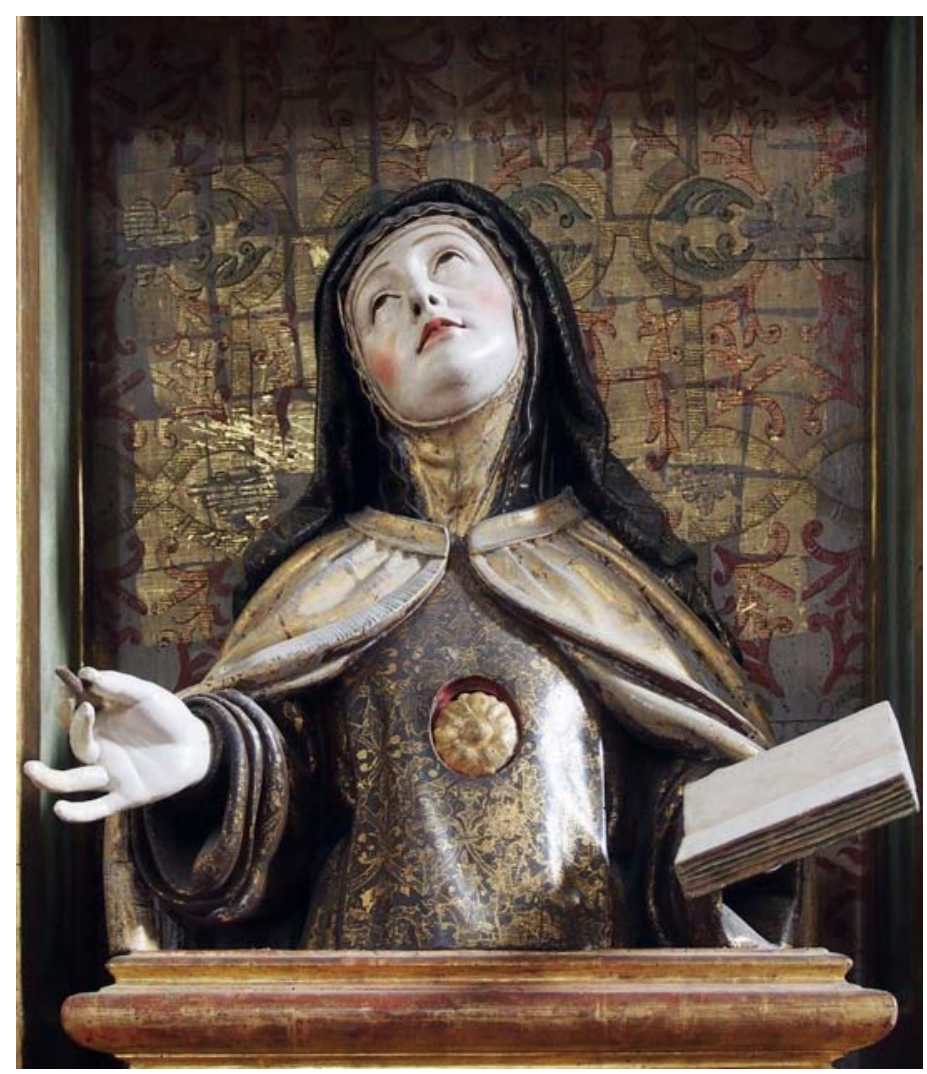

Fig. 19. Antonio de Herrera. Relicario de Santa Teresa. Retablo mayor de Moneo (Burgos).

121 Juan José Martín GonZÁlez, 1980, pp. 260-263.

122 La talla de Moneo recuerda a la imagen de medio cuerpo de la santa que se conserva en el Convento de las Carmelitas Descalzas de Alcalá de Henares. Juan Dorao FernÁndez, “Imagen y palabra en Teresa de Jesús”, en Teresa de Jesús. La prueba de mi verdad, Madrid, Biblioteca Nacional. Acción Cultural Española, 2015, pp. 84-85.

123 La conducta seguida por este matrimonio sería semejante a la de otros miembros de las élites sociales de la época, como analiza para el caso de Sicilia, Doménico LigRESTI, "Le piccole corti aristocratiche nella Sicilia spagnola", en Espacios de poder: cortes. Ciudades y villas (s. XVI-XVIII), vol. I, Madrid, UAM, 2002, pp. 231-249, el trabajo de Angelantonio SPAGNOLETTI, Principi italiani e Spagna nell'età barocca, Milán, Bruno Mondadori, 1996 y la aportación de Francesco BeNIGNO, "Aristocrazia e stato in Sicilia nell'epoca di Filippo III”, en M.A. Visceglia, Signori, patrizi, cavalieri nell' età moderna, Roma, Bari, 1999 , pp. 76-93. 
Nos hallamos, pues, ante un conjunto pictórico y escultórico de gran valor que es reflejo del devenir personal, gusto estético e ideología de sus promotores, Bartolomé Martínez de Quintana e Isabel de Franqui, marcado por un elevado sentimiento religioso, transportando a la modesta localidad burgalesa de Moneo, obras de arte de Sicilia y de la corte madrileña de fines del siglo XVI y primeras décadas de la decimoséptima centuria, que reflejan su interés por el alhajamiento de sus residencias, entrando en contacto para ello con notables artífices de las localidades en las que residieron, mostrando una conducta característica de las élites sociales españolas y sicilianas de la época ${ }^{123}$.

RENÉ JESÚS PAYO HERNANZ. Catedrático de Historia del Arte de la Universidad de Burgos. Vicerrector de Cultura de la Universidad de Burgos. Comisionado de Patrimonio Cultural de la Provincia de Burgos. Vicedirector de la Real Academia Burgense de Historia y Bellas Artes. Académico Correspondiente de las Reales Academias de la Historia y de Bellas Artes de San Fernando. Comisario de varias exposiciones sobre patrimonio artístico.

Email: rpayo@ubu.es

Código ORCID: https://orcid.org/0000-0003-2502-8598

JOSÉ MATESANZ DEL BARRIO. Profesor Asociado de Historia del Arte de la Universidad de Burgos. Profesor de Enseñanza Secundaria. Miembro de la Real Academia Burgense de Historia y Bellas Artes. Experto en arte de los siglos XVII y XVIII. Autor de 5 libros y 20 artículos sobre patrimonio arquitectónico de la Edad Moderna. Comisario de la exposición Hilos de Flandes. La colección de Tapices de la Catedral de Burgos.

Email: jmatesanz@ubu.es

Código ORCID: https://orcid.org/0000-0003-3086-227X 